NBER WORKING PAPER SERIES

\title{
WHERE DOES REGULATION HURT? EVIDENCE FROM NEW BUSINESSES ACROSS COUNTRIES
}

\author{
Silvia Ardagna \\ Annamaria Lusardi \\ Working Paper 14747 \\ http://www.nber.org/papers/w14747
NATIONAL BUREAU OF ECONOMIC RESEARCH
1050 Massachusetts Avenue
Cambridge, MA 02138
February 2009

We would like to thank Mary Burke, Steve Davis, Burcu Duygan-Bump, Gita Gopinath, Leora Klapper, Josh Lerner, Norman Loyaza, Maria Luengo-Prado, Ramana Nanda, Ana Maria Oviedo, Paul Reynolds, Fabio Schiantarelli, Antoinette Schoar, Luis Serven, Luigi Zingales, and seminar participants at the Harvard Junior Faculty workshop, the Harvard Business School International Research Conference, Northeastern University, and the Federal Reserve Bank of Boston for spurring our interest on this topic, providing comments on the model, and helping with the data and the empirical work. Any errors are our responsibility. The views expressed herein are those of the author(s) and do not necessarily reflect the views of the National Bureau of Economic Research.

NBER working papers are circulated for discussion and comment purposes. They have not been peerreviewed or been subject to the review by the NBER Board of Directors that accompanies official NBER publications.

(C) 2009 by Silvia Ardagna and Annamaria Lusardi. All rights reserved. Short sections of text, not to exceed two paragraphs, may be quoted without explicit permission provided that full credit, including (C) notice, is given to the source. 
Where does regulation hurt? Evidence from new businesses across countries

Silvia Ardagna and Annamaria Lusardi

NBER Working Paper No. 14747

February 2009

JEL No. E0

\begin{abstract}
$\underline{\text { ABSTRACT }}$
We use two micro data sets that collect harmonized data across countries to investigate the effects of regulation on new businesses. We are able to distinguish between two types of entrepreneurs: those who start a business to pursue a business opportunity and those who start a business because they could not find better work. Irrespective of the measure of regulation we use, we always find a detrimental effect of regulation on entrepreneurship. While women are overall less likely to start new businesses, in more regulated countries women are pulled into entrepreneurship not to pursue a business opportunity but because they could not find better work. Moreover, regulation dampens the effects of self-assessed business skills and social networks. In more regulated economies, those with better business skills and those who know other entrepreneurs are less likely to become entrepreneurs to pursue a business opportunity. Tighter regulation also exacerbates fear of failure, further discouraging business start-up. All our estimates point to a negative effect of regulation.
\end{abstract}

Silvia Ardagna

Department of Economics

Harvard University

Littauer Center

Cambridge, MA 02138

sardagna@fas.harvard.edu

Annamaria Lusardi

Department of Economics

Dartmouth College

Hanover, NH 03755

and NBER

a.lusardi@dartmouth.edu 


\title{
Where does regulation hurt? Evidence from new businesses across countries
}

\author{
Silvia Ardagna and Annamaria Lusardi* \\ Harvard University; Dartmouth College and NBER
}

February 2009

\begin{abstract}
We use two micro data sets that collect harmonized data across countries to investigate the effects of regulation on new businesses. We are able to distinguish between two types of entrepreneurs: those who start a business to pursue a business opportunity and those who start a business because they could not find better work. Irrespective of the measure of regulation we use, we always find a detrimental effect of regulation on entrepreneurship. While women are overall less likely to start new businesses, in more regulated countries women are pulled into entrepreneurship not to pursue a business opportunity but because they could not find better work. Moreover, regulation dampens the effects of self-assessed business skills and social networks. In more regulated economies, those with better business skills and those who know other entrepreneurs are less likely to become entrepreneurs to pursue a business opportunity. Tighter regulation also exacerbates fear of failure, further discouraging business start-up. All our estimates point to a negative effect of regulation.
\end{abstract}

\section{Introduction}

A growing body of academic and policy work emphasizes the importance of entrepreneurs and of countries' regulatory and legal environment for economic growth

\footnotetext{
${ }^{*}$ We would like to thank Mary Burke, Steve Davis, Burcu Duygan-Bump, Gita Gopinath, Leora Klapper, Josh Lerner, Norman Loyaza, Maria Luengo-Prado, Ramana Nanda, Ana Maria Oviedo, Paul Reynolds, Fabio Schiantarelli, Antoinette Schoar, Luis Serven, Luigi Zingales, and seminar participants at the Harvard Junior Faculty workshop, the Harvard Business School International Research Conference, Northeastern University, and the Federal Reserve Bank of Boston for spurring our interest on this topic, providing comments on the model, and helping with the data and the empirical work. Any errors are our responsibility.
} 
and development. As Aghion and Howitt (1997) suggest, new entrepreneurial activities play a vital part in the process of creative destruction that fosters innovation, employment, and growth. One way in which the regulatory and legal environment can impact growth and employment is its effect on the rate at which new businesses are created. While entrepreneurship has been so far largely treated as a homogeneous phenomenon, Ardagna and Lusardi (2008b) show that entrepreneurs differ widely in terms of personal characteristics, motivation to start new enterprises, types of businesses created, and ability to contribute to countries' growth and development. Moreover, entrepreneurship is not always a desired activity at the individual level, and individuals for whom entrepreneurship is a necessity/remedial activity may wish to exit entrepreneurship and work for an employer.

Mostly because of data limitation, there is a lack of research on the effect of economic policies on different types of entrepreneurship. Certain types of economic policies may be recommended because they support the creation of new businesses. However, not much is known about whether these policies support the type of entrepreneurship that is most beneficial for both the macroeconomy and individual well-being, or whether they simply foster self-employment in low-skilled, low-paid sectors. From a policy perspective, it is important to be able to distinguish between these cases. In this paper, we aim to enhance our knowledge of the individual characteristics and economic policies that encourage different types of entrepreneurship activities.

We focus on a specific set of economic policies - entry regulation in product markets, regulation of contract enforcement, and labor market regulation - and we investigate how regulation in these areas impacts two very distinct types of entrepreneurs: those who want to become entrepreneurs to pursue a business opportunity (opportunity entrepreneurs) and those who undertake entrepreneurship because they cannot find a better alternative (remedial/necessity entrepreneurs). We begin our analysis by introducing regulation in a static occupational choice model based on the work of Lucas (1978) and Evans and Jovanovic (1989). We study both the direct and indirect effect of regulation on the individual decision to start a new business, via the effect of regulation on the return of a wide-ranging set of individual characteristics, including business skills, fear of failure, and social networks. We then take our model to the data to test its implications.

Because our model relies on individual characteristics of entrepreneurs, we use cross-national harmonized micro data on entrepreneurship collected by Global Entrepreneurship Monitor (GEM) in 40 developed and developing countries, and we merge these data with cross country macro data on regulation to capture differences in regulatory constraints. We also perform our analysis on a smaller sample of countries using micro data from the Flash Eurobarometer Surveys on Entrepreneurship collected by the European Commission. 
Irrespective of the data sets and measure of regulation we use, we find that regulation is a detriment to entrepreneurial activity, particularly for those individuals who become entrepreneurs to pursue a business opportunity. Our results show that regulation affects the individual decision to start a new business by changing the return of certain personal characteristics. In more heavily regulated countries, those who have business skills, know other entrepreneurs, and have less fear of failure are, in fact, less likely to engage in entrepreneurship than in less regulated countries. Moreover, in countries with higher regulation, women and those who do not work are more likely to be pulled into necessity entrepreneurship. Since women and the unemployed are already vulnerable groups, regulation can end up having truly harmful effects.

Our estimates also point to some alternative ways in which entrepreneurship can be supported. Raising education is among the most effective policies to foster entrepreneurship. Increasing educational attainment can achieve several important objectives: not only does education foster entrepreneurship but it pulls would-be entrepreneurs into pursuing business opportunity while it discourages necessity entrepreneurship. Related to education, we also find that those who have business skills are more likely to enter entrepreneurship. Thus, teaching or fostering relevant skills in school or in training programs may be another way to foster entrepreneurship. Finally, peers and social networks are also important for entrepreneurship. Therefore, encouraging or creating business clusters could also jump-start entrepreneurship. Once again, these effects are greater for those who engage in opportunity entrepreneurship, the type of entrepreneurship that is more beneficial for the macroeconomy and individual well-being.

This paper contributes to two distinct strands of literature: the entrepreneurship literature and the institutional literature. In the entrepreneurship literature, there are relatively few studies that investigate the factors affecting individual decisions to engage in new entrepreneurial activity in a broad sample of countries. Most of the literature uses micro data from one particular country, the United States in the majority of the cases. Also, with the exception of Djankov et al. (2005), (2006a), (2006b), and (2008), who investigate the role of a broad set of macro and micro variables on entrepreneurship in Russia, China, and Brazil, empirical research has focused on a limited number of individual characteristics. ${ }^{1}$ Moreover, while the literature has focused on tax policy and liquidity constraints, ${ }^{2}$ our paper looks at

\footnotetext{
${ }^{1}$ See, for example, the papers by Blanchflower (2000, 2004), Blanchflower, Oswald, and Stutzer (2001), and Blanchflower and Oswald (1998), and the review in Hurst and Lusardi (2004, 2008).

${ }^{2}$ See, for example, the work by Djankov et al. (2007), Gentry and Hubbard (2000), Evans and Jovanovic (1989), Guiso et al. (2004), Hurst and Lusardi (2004, 2008). See also Alfaro and Charlton (2007) for the effects of international financial integration on entrepreneurship and Malesky and Taussig (2008) for the effect of quality of governance institutions on entrepreneurship in Vietnam.
} 
other types of regulation, such as the regulation of the product and labor markets and contract enforcement. In this respect, our paper relates to the work of Ciccone and Papaioannou (2006), Desai et al. (2003), Klapper et al. (2006), and Guiso and Schivardi (2007), who investigate the role of regulation in product markets on industries' entry rates and on several other firm characteristics using firm level data from developed and transitional countries. Finally, in the institutional literature, there is quite a large body of evidence on the effects of regulation of product and labor markets on GDP growth, TFP, investment, and employment using macro data. $^{3}$ However, less work has been done on how a country's regulatory and legal environment affects decisions at the micro level, as we do in this paper.

This paper is organized as follows: Section 2 presents the model; Section 3 describes our data and presents some descriptive statistics; Section 4 discusses the empirical methodology and our results; Section 5 includes a discussion of our findings and the last section concludes.

\section{The model}

We use a simple model to show the effect of regulation on the individual decision to engage in a new entrepreneurial activity. The model is static and extends the work of Lucas (1978) and Evans and Jovanovic (1989) by introducing regulation and considering its impact on entrepreneurship both directly and via the interaction between countries' regulation and individual characteristics. As we show below, this extension is important because regulation can also affect the return on certain individual characteristics such as education, business skills, and attitude toward risk.

At the beginning of each period, a risk-neutral individual has to decide whether to continue his current employment status or to start a new business activity. His current employment status yields him an income $\bar{y}$ that is exogenous and independent of his individual characteristics. The new business, instead, yields him gross returns equal to $y=\widetilde{A} k^{\alpha}$ where $y$ is output, $k$ is the amount of capital invested in the business activity, and $\alpha<1$ is the capital share. For simplicity, we assume that output is produced using capital as the only factor of production. However, we can explicitly account for labor in the production process using a Cobb-Douglas production function as, for example, in Guiso and Schivardi (2007), and the results we obtain below do not change. Finally, $\widetilde{A}$ measures the entrepreneur's productivity in the new business. To describe the entrepreneurial technology, we follow Lucas (1978) and assume that $\widetilde{A}=A X^{\beta}$. A is the entrepreneur's talent or ability and is

\footnotetext{
${ }^{3}$ See Alesina et al. (2005), Bassanini and Ernst (2002), Bayoumi et al. (2004), Blanchard and Wolfers (2000), Fiori et al. (2007), Loayza et al. (2004), Nicoletti and Scarpetta (2003).
} 
drawn from a random variable with distribution function $\gamma(A)$ and corresponding cumulative distribution function $\Gamma(A) ; X$ captures observable individual characteristics such as age, gender, education, social networks, business skills, and risk attitude; $\frac{\partial \widetilde{A}}{\partial X}>0, \frac{\partial^{2} A}{\partial X^{2}}<0$ and $\beta<1$.

Regulation imposes a cost $C=f+v k$ composed of a fixed component $f$ and of a variable part $v$ proportional to the amount of capital invested in the business. The sunk cost component captures administrative procedures and other costs (e.g., costs for licenses) that the entrepreneur has to incur to be able to start the business activity. The variable component, instead, measures other costs that the regulatory burden can impose on firms. For example, in a country in which the legal system is not fair or efficient, going to court can be very costly for firms and it seems reasonable to assume that such costs are proportional to the amount of capital invested. ${ }^{4}$

\subsection{The entrepreneur's problem}

In each period, the entrepreneur chooses the level of capital that maximizes expected profits.

$$
\max _{k}\left[\tilde{A} k^{\alpha}-r k-v k-f\right]
$$

The first order condition for this problem yields the solution for the optimal level of capital.

$$
k^{*}=\left[\frac{\widetilde{A} \alpha}{r+v}\right]^{\frac{1}{1-\alpha}}
$$

Substituting equation (2) and the equation that describes the entrepreneurial technology $\widetilde{A}=A X^{\beta}$ in the firm's profit function gives an expression for the optimal level of profits the entrepreneur expects at the beginning of the period as a function of the entrepreneur's talent $A$, his characteristics $X$, the interest rate $r$, the parameters capturing the costs imposed by regulation, $f$ and $v$, and the technology parameters $\alpha$ and $\beta$.

$$
E\left(\pi^{*}\right)=\left[A^{\frac{1}{1-\alpha}} X^{\frac{\beta}{1-\alpha}}(r+v)^{-\frac{\alpha}{1-\alpha}} \alpha^{\frac{\alpha}{1-\alpha}}(1-\alpha)\right]-f
$$

Ceteris paribus, an increase in the entrepreneur's productivity (due to both an increase in $A$ or in $X$ ) leads to an increase in the optimal level of expected profits, while an increase in $v$ or $f$ leads to a decrease in $E\left(\pi^{*}\right)$. Moreover, note that in an environment in which the regulatory burden is heavier ( $v$ is higher), an increase of

\footnotetext{
${ }^{4}$ If we explicitly account for labor in the production process as, for example, in Guiso and Schivardi (2007), regulatory costs can be assumed to be proportional to labor as well, and this could be a simple way to capture the costs imposed by labor regulation.
} 
the entrepreneur's productivity leads to a lower increase in $E\left(\pi^{*}\right)$ than in a country in which $v$ is lower (i.e. $\frac{\partial^{2} E\left(\pi^{*}\right)}{\partial A \partial v}<0$ and $\frac{\partial^{2} E\left(\pi^{*}\right)}{\partial X \partial \partial}<0$ ). Suppose, for example, that the entrepreneur's productivity in the new business is higher the more educated the entrepreneur is or the higher the amount of social capital he has accumulated (i.e., $X$ is higher). If the entrepreneur acquires an additional year of education or invests his time to build up more social capital, the benefits from such activities, measured in terms of profit from his new business, are lower in more regulated countries.

\subsection{The decision to start a new business}

An individual chooses to start a new entrepreneurial activity if he expects that the net income from doing so will be higher than the income he receives from his current occupation, that is if:

$$
E\left(\pi^{*}\right)=\left[A^{\frac{1}{1-\alpha}} X^{\frac{\beta}{1-\alpha}}(r+v)^{-\frac{\alpha}{1-\alpha}} \alpha^{\frac{\alpha}{1-\alpha}}(1-\alpha)\right]-f \geqslant \bar{y}
$$

Because $E\left(\pi^{*}\right)$ is increasing in $A$ and because we are assuming that $\bar{y}$ does not depend on $A$, there will be a unique value of $A=\bar{A}$ at which the marginal individual is indifferent between remaining in his current occupation or starting the new business activity:

$$
\bar{A}=[\bar{y}+f]^{1-\alpha} X^{-\beta}(r+v)^{\alpha} \alpha^{-\alpha}(1-\alpha)^{-(1-\alpha)}
$$

Equation (5) defines the level of $A$ above which it is optimal for the individual to engage in entrepreneurship: higher ability individuals (i.e.: those whose $A \geqslant \bar{A}$ ) choose to start a new entrepreneurial activity, the others do not. An increase in the regulatory burden, measured both by its fixed component $f$ or by its variable component $v$, increases the level of talent above which it is optimal to start a new business $\left(\frac{\partial \bar{A}}{\partial f}>0, \frac{\partial \bar{A}}{\partial v}>0\right)$. To the contrary, an increase in $X$ decreases the level of talent above which it is optimal to start a new business $\left(\frac{\partial \bar{A}}{\partial X}<0\right)$.

Finally, we can compute how changes in regulation and in individual characteristics influence the individual probability of starting a new business. First, the individual probability of starting a new business is decreasing in the regulatory burden and increasing in $X$ :

$$
\begin{aligned}
& \frac{\partial(1-\Gamma(\bar{A}))}{\partial f}=-\frac{\partial \Gamma(\bar{A})}{\partial \bar{A}} \frac{\partial \bar{A}}{\partial f}=-\gamma(\bar{A}) \frac{\partial \bar{A}}{\partial f}<0 \\
& \frac{\partial(1-\Gamma(\bar{A}))}{\partial v}=-\frac{\partial \Gamma(\bar{A})}{\partial \bar{A}} \frac{\partial \bar{A}}{\partial v}=-\gamma(\bar{A}) \frac{\partial \bar{A}}{\partial v}<0
\end{aligned}
$$




$$
\frac{\partial(1-\Gamma(\bar{A}))}{\partial X}=-\frac{\partial \Gamma(\bar{A})}{\partial \bar{A}} \frac{\partial \bar{A}}{\partial X}=-\gamma(\bar{A}) \frac{\partial \bar{A}}{\partial X}>0
$$

Furthermore, note that the individual probability of starting a new business depends on the interaction between regulation and personal characteristics. In fact, $\frac{\partial^{2}(1-\Gamma(\bar{A}))}{\partial f \partial X}$ and $\frac{\partial^{2}(1-\Gamma(\bar{A}))}{\partial v \partial X}$ are nonzero if $\eta_{\gamma(\bar{A}), \bar{A}}=\frac{\frac{\partial \gamma(\bar{A})}{\partial \bar{A}}}{\frac{\gamma(\bar{A})}{\bar{A}}} \neq-1$ where $\eta_{\gamma(\bar{A}), \bar{A}}$ is the elasticity of the density function with respect to the entrepreneur's talent computed at the threshold value $\bar{A}$. More specifically, an increase in the regulatory burden, due either to an increase of its fixed component $f$ or its variable part $v$, reduces the positive effect of personal characteristic $X$ on the likelihood of engaging in entrepreneurship if $\eta_{\gamma(\bar{A}), \bar{A}}<-1$ and it increases the positive effect of $X$ if $\eta_{\gamma(\bar{A}), \bar{A}}>-1$.

Note that for many continuous density functions, this condition translates to a condition on the derivative of $\bar{A}$ with respect to the regulation parameters $f$ and $v$ being larger/smaller than some particular values. If $A$ is normally distributed, then ${ }^{5}$

$$
\frac{\partial^{2}(1-\Gamma(\bar{A}))}{\partial f \partial X}<0 \text { if } \frac{\partial \bar{A}}{\partial f}>\frac{1-\alpha}{[\bar{y}+f]}
$$

and

$$
\frac{\partial^{2}(1-\Gamma(\bar{A}))}{\partial v \partial X}<0 \text { if } \frac{\partial \bar{A}}{\partial v}>\frac{\alpha}{[r+v]}
$$

Hence, a sufficient condition for heavier regulation to lead to a reduction of the positive effect that an increase in $X$ has on the likelihood of engaging in entrepreneurship is that an increase in the regulatory burden (i.e., higher $f$ or $v$ ) increases the level of talent above which it is optimal for an individual to start a new business by more than $\frac{1-\alpha}{[\bar{y}+f]}$ or $\frac{\alpha}{[r+v]}$ respectively.

Summarizing, in the context of the simple model above, an increase in the regulatory burden influences entrepreneurship through two channels. First, a higher value of $f$ or $v$ leads to a decrease of the probability that an individual will start a new business activity because it decreases expected profits from the new activity and increases the productivity level above which it is optimal for an individual to engage in entrepreneurship. Second, heavier regulation has an indirect effect on the likelihood of engaging in entrepreneurship via the interaction between countries' regulation and individual characteristics. When an increase in the regulatory burden raises substantially the level of talent above which it is optimal for an individual to engage in entrepreneurship, heavier regulation moderates the effect of the

\footnotetext{
${ }^{5}$ One obtains similar conditions if $A$ is distributed according to a gamma, Weibull, exponential, or logistic distribution.
} 
entrepreneur's observable characteristics on the probability of starting a new business activity. While the direct effect of regulation on entrepreneurship is negative, the indirect effect that regulation has on the likelihood of engaging in entrepreneurship via the interaction between countries' regulation and individual characteristics is ambiguous and depends on parameters' values. Overall, whether regulation has a beneficial or detrimental effect on the individual decision to start a new business activity has to be determined empirically and the scope of the empirical analysis that follows is precisely to understand whether entrepreneurship flourishes in more or in less regulated environments.

\section{Data: GEM and the Flash Eurobarometer}

In order to test the implications of our model we need micro data on entrepreneurship, as our model relies on the individual characteristics of entrepreneurs. Moreover, we need data across countries to capture differences in regulatory constraints. We use survey data collected by Global Entrepreneurship Monitor (GEM) and the Flash Eurobarometer.

GEM is a research program that started in 1998 and that annually collects crossnational harmonized data on entrepreneurship. This is one of the few surveys that provide data on entrepreneurship across countries and a rich set of characteristics on entrepreneurs. Each year GEM surveys either by phone or face-to-face interviews a sample of at least 2,000 randomly selected individuals in each country (the Adult Population Survey). ${ }^{6}$ The surveys we use refer to the years 2001, 2002, and 2003. These are the most recent surveys available to researchers and include information both on individuals' decisions to engage in entrepreneurial activity and on individuals' motivations to start a new business. Countries included in our sample cover a wide spectrum, from the Organization for Economic Co-operation and Development (OECD) countries to Latin American, European and Central Asian (ECA), and East Asian and Pacific (EPA) countries. ${ }^{7}$

GEM surveys offer several advantages for our work. First, it reports harmonized data on entrepreneurship across many countries. This is very important since there are many different definitions of entrepreneurship both within and across

\footnotetext{
${ }^{6}$ See Reynolds et al. (2005) for more information on the GEM project and the data collection process.

${ }^{7}$ The complete list is Argentina, Australia, Belgium, Brazil, Canada, Chile, China, Croatia, Denmark, Finland, France, Germany, Greece, Hong Kong, Hungary, India, Ireland, Israel, Italy, Japan, South Korea, Mexico, the Netherlands, New Zealand, Norway, Poland, Portugal, Russia, Singapore, Slovenia, South Africa, Spain, Sweden, Switzerland, Taiwan, Thailand, Uganda, United Kingdom, United States, and Venezuela.
} 
countries and it is critical to be able to make consistent comparisons. ${ }^{8}$ Second, it allows us to distinguish between two very distinct types of entrepreneurs: those who want to become entrepreneurs to pursue a business opportunity (opportunity entrepreneurs hereafter) and those who undertake entrepreneurship because they cannot find a better alternative (remedial/necessity entrepreneurs hereafter). The ability to distinguish between "opportunity" and "necessity" entrepreneurs is crucial for our empirical analysis. On the one hand, our model relies on the fact that an individual chooses to start a new entrepreneurial activity if he expects that the net income from doing so will be higher than the income he receives from his current occupation. Hence, opportunity entrepreneur seems to be an ideal characterization of those who set up a business in our model. On the other hand, we work with a variety of countries, and incentives to become entrepreneurs are very different between, for example, developed and developing countries. Moreover, entrepreneurship is not always a desired activity either at the individual or at the macro level. ${ }^{9}$ Individuals for whom entrepreneurship is a necessity may wish to exit entrepreneurship and work for an employer. Similarly, policies that simply support remedial/necessity entrepreneurship may end up being counterproductive. Third, GEM provides a rich set of characteristics to study entrepreneurship, such as attitudes toward risk, self-assessed business skills, and relationship with other entrepreneurs. These are critical variables to explain entrepreneurship and are not present in many other cross-national surveys.

We also use data from the Flash Eurobarometer survey. This survey reports information similar to that reported by GEM. It collects data on entrepreneurship across developed, Eastern European, and transitional economies ${ }^{10}$ over several years, starting with 2000. We use only the 2004 and 2007 surveys because they are the only ones that include information both on individuals' decisions to engage in entrepreneurial activity and individuals' motivations to start a new business, allowing us to separate necessity and opportunity entrepreneurs, as in GEM data. In Flash Eurobarometer, the number of observations for each country is often smaller than in GEM data. Moreover, relative to GEM data, Flash Eurobarometer provides a less rich set of characteristics to study entrepreneurship. For example, it is not

\footnotetext{
${ }^{8}$ See, among others, Blanchflower (2004), Evans and Jovanovic (1989), Hurst and Lusardi (2004), Gentry and Hubbard (2000).

${ }^{9}$ For example, according to Mondragon-Velez and Pena-Parga (2008), many of those who enter self-employment in Colombia earn low returns. Similar results are reported in Sri Lanka (de Melo, McKenzie and Woodruff (2008)).

${ }^{10}$ The complete list is Austria, Belgium, Cyprus, Czech Republic, Denmark, Estonia, Finland, France, Germany, Greece, Hungary, Ireland, Italy, Latvia, Lichtenstein, Lithuania, Luxembourg, Malta, the Netherlands, Norway, Poland, Portugal, Slovakia, Slovenia, Spain, Sweden, United Kingdom, and United States.
} 
possible to investigate whether self-assessed business skills are important for entrepreneurship because the information is not available in the data. However, we use these data both to check and validate our results from GEM and, as explained in Section 4, to be able to test all the predictions on the effect of regulation on entrepreneurship that the model in Section 3 delivers.

As explained in detail in Ardagna and Lusardi (2008a), we have performed a thorough analysis to assess the quality and reliability of the data. We have compared GEM data with the Flash Eurobarometer Survey on Entrepreneurship to check consistency of results between these two surveys. We find that the statistics about entrepreneurship between these two surveys match very well. Moreover, we have estimated the probability of starting a business as a function of a set of demographic characteristics that are available in GEM and Flash Eurobarometer data both by country and by year. We have examined whether the estimates from these regressions are consistent with the results from other studies on specific countries. For example, we have compared these regressions with the estimates of other studies in the United States and found very similar results. We have also found consistent results for countries like Italy, Brazil, and China, where data was collected using questions similar to those present in GEM and/or Flash Eurobarometer surveys. Finally, we have analyzed the data for each country across years to examine whether there are any major changes or anomalous results, but we found that the data is consistent across years in the majority of countries included in the datasets. $^{11}$

\subsection{Entrepreneurship and regulation: Descriptive evidence}

GEM and Flash Eurobarometer provide information on total entrepreneurial activity ( $T E A) . T E A$ is an indicator variable equal to one if individuals are starting a new business or are owners and managers of a young firm; it is equal to zero otherwise. $T E A$ can be further split into entrepreneurial type: opportunity entrepreneurial activity ( $T E A O P P$ ) and necessity entrepreneurial activity (TEANEC). $T E A O P P$ is an indicator variable equal to one if individuals are starting a new

\footnotetext{
${ }^{11}$ See Ardagna and Lusardi (2008a) for a detailed discussion of the quality of data. In particular, for the GEM data, Reynolds et al. (2005) compare GEM national annual new firms' estimates and new firms' birth rates with data from the Official New Firm Census and data from the European Commission Report. They show that the entrepreneurship indices computed using GEM data are reliable and capture the creation of new firms on a scale comparable to that resulting from the use of other national administrative datasets. Acs et al. (2007) compare GEM data with the World Bank Group Entrepreneurship Survey (WBGES) data set, which collected data on formal business registrations of limited liability corporations (LLCs) in 84 countries from 2003 to 2005. The authors report a number of differences in the two data sets. However, as discussed in Ardagna and Lusardi (2008a), the differences are mostly due to the definitions of entrepreneurship used in the two surveys.
} 
business or are owners and managers of a young firm to take advantage of a business opportunity; it is equal to zero otherwise. TE ANEC is an indicator variable equal to one if individuals are starting a new business or are owners and managers of a young firm because they could find no better economic work; it is equal to zero otherwise. ${ }^{12}$ Thus, our focus is on firms at the initial planning or inception stage. Our data represents the potential supply of entrepreneurs rather than the actual rate of entrepreneurship. This is a specific definition that differs from what other papers have used so far, but it is appropriate given the focus of this paper, because it allows us to concentrate on the start-up phase and on the first few years of a new business, rather than on well-established firms that have been active for many years and upon which, for example, the regulatory environment can have different effects. ${ }^{13}$

To assess the effects of regulation, we add data on countries' institutional and regulatory environments. We follow the work of Loayza et al. (2004), and construct indices on several aspects of market regulation. ${ }^{14}$ In particular, we focus on entry regulatory indicators for the product markets, regulation of contract enforcement (indicators measuring the efficiency of the justice system in resolving legal disputes), and labor market regulation. While these aspects of regulation do not cover all regulatory and economic policies, they include some of the most important regulatory constraints across countries.

The indices we use in our empirical work are as follows:

Entry: The entry index measures the barriers and costs entrepreneurs face when they decide to create a new business. It is the average of the number of

\footnotetext{
${ }^{12}$ GEM defines as individuals starting a new business those who (i) alone or with others are currently trying to start a new business, including any type of self-employment, or (ii) alone or with others are trying to start a new business or a new venture together with their employer as an effort that is part of their normal work, and who (a) have been active in the past 12 months in trying to start the new business, (b) expect to own part of it, and (c) have not paid salaries and wages to anybody, including the owner/managers, for more than 3 months. Individuals who are owners and managers of a young firm are individuals who, alone or with others, are the owners of a company they help manage, provided that the company has been paying salaries and wages for no more than 42 months. Flash Eurobarometer defines as individuals starting a new business those who (i) are currently taking steps to start a new business, or (ii) have started or taken over a business in the last three years and the business is still active at the time of the interview. Appendix II reports the survey questions that the GEM coordination team uses to generate the variables $T E A, T E A O P P, T E A N E C$. The exact methodology is based on procedures previously used in the U.S Panel Study of Entrepreneurial Dynamics, and it is described in detail in the 2001 and 2002 Adult Population Surveys' data documentation and in Reynolds et al. (2005). Appendix III reports the Flash Eurobarometer survey questions used to generate the variables TEA, TEAOPP, TEANEC.

${ }^{13}$ One reason to consider the nascent and the early stage entrepreneurs together is that the size of these two groups can be quite small, particularly in European countries.

${ }^{14}$ We construct our own indices, rather than using the ones provided to us by Loayza et al. (2004) because regulatory variables for several countries included in our sample are not available in Loayza et al. (2004).
} 
procedures that are officially required to start and operate a new business, the time and cost of completing such procedures, and a composite index measuring not only how easy/difficult it is to operate a business but also the degree of corruption in the government and whether or not regulation is applied uniformly to all businesses.

Contract: The contract enforcement index measures the efficiency of the justice system in resolving commercial disputes. It is the average of the number of procedures required to solve a dispute and of an index measuring the ability of the government to operate without dramatic changes in policy or interruptions of its services.

Labor: The labor index measures the difficulty for entrepreneurs of adjusting the labor force. It is the average of indices measuring the difficulty in hiring and firing workers, the rigidity of labor contracts, and the percentage of the workforce affiliated with labor unions.

The data we use are from a variety of sources: Doing Business Database (the World Bank Group), Index of Economic Freedom (the Heritage Foundation), International Country Risk Guide (the PRS Group), and Djankov et al. (2004). Appendix I lists the exact source, time period, and definition of each regulatory variable used in the empirical analysis.

Because our indices of regulation combine several different variables, we standardize each variable available in the databases using the formula $\frac{X_{i}-X_{\min }}{X_{\max }-X_{\min }}$ when higher values of the variable $X$ indicate heavier regulation and the formula $\frac{X_{\max }-X_{i}}{X_{\max }-X_{\min }}$ when lower values of the variable $X$ indicate heavier regulation. Hence, each standardized regulatory variable is simply an index ranging from 0 to 1 , increasing with the amount of regulation. For each area of regulation, we construct a synthetic indicator of the tightness of regulation. Each synthetic indicator is the average of the standardized indices measuring regulation of the relevant area. Use of these indices allows us to compare our results to previous studies and to capture many different aspects of regulation in the three areas we consider. ${ }^{15}$

Given that we have a different sample, we first compute the correlation of the indices we constructed with the ones of Loayza et al. (2004). For our larger sample, which includes all the countries surveyed in GEM, the correlation is equal to 0.98 for the entry regulatory index, 0.82 for the contract enforcement regulation index, and 0.83 for the labor market regulation index. Thus, even though our sample of countries differs from that of Loayza et al. (2004), our indices are very similar. Second, we examine the correlation across indices. While the Entry and Contract indices measure different aspects of regulation, the two are highly positively correlated. The correlation of these two indices and the Labor index is rather low, indicating that the regulation in labor markets often differs from the regulation

\footnotetext{
${ }^{15}$ For each index we construct, a higher value corresponds to tighter regulation.
} 
in other markets. When we further look at the correlation among the components of each synthetic index, in all areas but the labor market we again find a positive correlation that ranges from a minimum of $38 \%$ to a maximum of $72 \%$. However, for the labor market index, we observe a very low correlation between indicators of hiring and firing costs and union density, and, in one case, the correlation is negative. Thus, regulation in the labor markets can have different effects than regulation in other markets. Given these findings, we consider these three indices of regulation separately in our empirical work.

We begin the empirical analysis with some descriptive statistics on the relationship between entrepreneurship and countries' regulatory environments. For brevity, we present only descriptive statistics based on GEM data. Results obtained using the Flash Eurobarometer data are consistent with those using GEM data and they are available upon request. Figure 1 reports the rate of entrepreneurship across countries in different income groups. ${ }^{16}$ As the figure illustrates, it is critically important to be able to distinguish between types of entrepreneurs. Entrepreneurship rates are highest among low-income countries and lowest among highincome countries, but the composition of entrepreneurship differs dramatically across countries. A very sizable proportion of entrepreneurship in low-income countries is simply necessity entrepreneurship, while the lion's share of entrepreneurship in high-income countries is made up of opportunity entrepreneurs. In fact, when we look at the ratio of opportunity entrepreneurship over necessity entrepreneurship, the ranking simply reverses: not only do the high-income countries have the highest ratio and the low-income countries have the lowest ratio, but the ratio in high-income countries is four times as high. Looking at regulation, we find that regulatory constraints, particularly entry and contract regulation, are highest in low-income countries and lowest in high-income countries. This negative correlation between regulation and income is hard to interpret; while regulation can affect income, countries with different income status may also adopt different regulatory policies. In Figure 1 we also report the rate of entrepreneurship and regulation across geographic regions and across legal origins, two classifications that are more exogenous to both entrepreneurship and regulatory constraints. This classification shows again that the ability to distinguish between opportunity and necessity entrepreneurship matters a great deal. Looking at the rate of entrepreneurship only, we find that Latin American countries display the highest rate of entrepreneurship while OECD or European Union countries display a much lower level of entrepreneurship. However, this statistic hides a fundamental difference between the type of entrepreneurs in these countries: While in OECD and EU countries, most of the entrepreneurs are opportunity entrepreneurs, in Latin America a very large share of

\footnotetext{
${ }^{16}$ See Appendix I for the list of countries in each income group.
} 
entrepreneurs are necessity entrepreneurs. Again, the ranking of countries simply reverses when we consider the ratio of opportunity over necessity entrepreneurs rather than the rate of entrepreneurship. Regulation by geographic region very closely mimics the pattern described by the ratio of entrepreneurial types in these countries. Regulation, particularly contract regulation, is highest in Latin America and lowest in EU and OECD countries. A similar pattern is obtained when we look across countries with different legal origins. Looking at the rate of entrepreneurship only, we find that Scandinavian countries have the lowest while English and French legal origin countries have the highest rates of entrepreneurship. However, it is the Scandinavian countries that display the highest ratio of opportunity over necessity entrepreneurship and these countries also have the lowest regulatory constraints, particularly with regard to entry and contract regulation. On the other hand, both Socialist and French origin countries have the highest level of (entry and contract) regulation and they have the lowest ratio of opportunity over necessity entrepreneurship.

As Figure 2 and Table 1 show, opportunity and necessity entrepreneurs start businesses that differ in several dimensions; thus, the effect on economic activity can vary widely. ${ }^{17}$ First, $40 \%$ of necessity entrepreneurs start activities in the retail, hotel, and restaurant sector; only $27 \%$ of opportunity entrepreneurs target this sector. The latter are, instead, more present in the business and consumer services sectors, and in the finance, insurance, and real estate sectors. Second, a larger fraction of opportunity entrepreneurs than of necessity entrepreneurs offers products and services that are considered new by their customers and are not provided by many other businesses. This suggests that opportunity entrepreneurs are more likely to contribute to product innovation than necessity entrepreneurs and to increase competition in areas where fewer incumbents operate. Third, the vast majority of necessity entrepreneurs (68.2\%) sell their products or services exclusively to domestic customers; $50 \%$ or more of the customers live in a foreign country for about $15 \%$ of opportunity entrepreneurs in our sample. Finally, opportunity and necessity entrepreneurship significantly differ in terms of job creation. Table 1 shows the average number of jobs created, or expected to be created in five years, at different points of the employment distribution. While in the bottom quartile of the employment distribution the number of employees hired by opportunity and necessity entrepreneurs is the same, employment creation is significantly different in the upper tail of the distribution. For example, in the 50th percentile of the employment distribution, opportunity entrepreneurs, on average, hired two employees and expect to hire four employees in five years. Necessity entrepreneurs hired only one

\footnotetext{
${ }^{17}$ See Appendix II for the exact wording of the questions used to compute the variables shown in Figure 2 and in Table 1.
} 
employee and expect to hire two employees in five years. This difference magnifies for businesses in the top $1 \%$ of the distribution: for opportunity entrepreneurs, current employment is at 150 workers and it is expected to grow, on average, to 500 workers; for necessity entrepreneurs, the same numbers are 50 and 150 .

While these simple statistics provide some prima facie evidence that regulation hinders entrepreneurship, it is in fact hard to draw inference from these aggregated data as countries' regulation can simply proxy for aggregate characteristics (growth rates, degrees of openness, level of taxation, etc.) that also influence entrepreneurship. We turn below to a more formal analysis of our model that explicitly exploits the micro data and investigates the channels described in our theoretical model.

\section{Econometric analysis}

According to our model, heavier regulation has a direct as well as an indirect effect on the likelihood of engaging in entrepreneurship via the interaction between countries' regulation and individual characteristics. We estimate these effects by using the following empirical specification: for individual $i$, in country $j$, at time $t$, the outcome of interest is $y_{i j t}$, where $y$ is one of the three measures of entrepreneurial activity: $T E A, T E A O P P, T E A N E C$. We estimate the following equation for $y_{i j t}$ :

$$
y_{i j t}=\alpha_{j}+\beta_{1} X_{i j t}+\beta_{2} X_{i j t} R_{j t}+\beta_{3} R_{j t}+\gamma_{t}+\varepsilon_{i j t}
$$

where $\alpha_{j}$ is a vector of country dummies; $X$ is a vector of variables measuring individual characteristics such as age, gender, employment status, education, income, the role of social networks, business skills, and fear of failure; $R$ captures countries' regulatory and legal environment; and $\gamma_{t}$ is a vector of time dummies. Since the dependent variable is binary, we use probit estimation and correct the standard errors by clustering them at the country level. ${ }^{18}$

Our sample includes many different countries whose macroeconomic and institutional characteristics, as explained above, can be correlated both with the entrepreneurship indices and with the regulatory variables. While we cannot separately account for each country's macroeconomic and institutional variables, we can control for countries' specific characteristics by adding country fixed effects to our regressions.

\footnotetext{
${ }^{18}$ In the regressions using the GEM data, we do not need to correct the standard errors as suggested by $\mathrm{Ai}$ and Norton (2003) and Norton, Wang, and $\mathrm{Ai}$ (2004) because of the dummy variable nature of our indicators and because, as explained below, the regulatory indices are not separately included in the regressions.
} 
In our benchmark regressions that use the micro data from the GEM Adult Population database, the regulatory variables are country and time invariant. ${ }^{19}$ Hence, once we include $\alpha_{j}$ among our regressors, we cannot estimate the coefficient $\beta_{3}$ and we can only measure the effect of regulation emphasized in our theoretical model by examining the differential effect that personal characteristics have on the decision to engage in entrepreneurial activity because of cross-country differences in the regulatory and legal environments. Thus, the parameter of interest is $\beta_{2}$. Negative values of $\beta_{2}$ in equation (11) indicate that heavier regulation reduces the effect of personal characteristics on the likelihood of engaging in entrepreneurship when $\beta_{1}$ in equation (11) is positive and reinforces the effect of personal characteristics when $\beta_{1}$ is negative. In other words, $\beta_{2}$ will indicate whether and how much regulation acts as a detriment or an encouragement to entrepreneurship.

In section 4.2, when we consider the Flash Eurobarometer data, we can exploit the time variation of the regulatory indices and estimate also the effect of regulation directly (i.e., we can estimate the coefficient $\beta_{3}$ ) in addition to its effect via individual characteristics.

\subsection{Empirical findings: Benchmark specifications}

In this section we report the results of our benchmark models that use the data from GEM. As mentioned above, we use a vector of variables $X$ measuring individual characteristics in our empirical work. Some, such as age, gender, education, working status, and income, have been used in other studies on entrepreneurship. Other variables to explain entrepreneurship, such as self-assessed business skills, attitudes toward risk, and social networks, are not present in many other surveys but are available in GEM data. We can therefore account for a rich set of individual characteristics in our empirical work. ${ }^{20}$ Appendix I provides a detailed description of the variables we use and their definitions. We report hereafter the description of some of the innovative variables we have used in our work. Self-assessed business skills (Skills) are measured by a dummy variable equal to 1 if an individual answers that he or she has the knowledge, skill, and experience to start a new business; the variable is equal to 0 otherwise. Fear of failure, a proxy for individual attitudes toward risk, is measured by the dummy variable Fear fail, which is equal to 1 for individuals who answer that fear of failing prevents them from starting a

\footnotetext{
${ }^{19}$ Most of the variables used to construct the regulatory indicators are from the World Bank Doing Business Database and refer to January 2003 as earlier data are not available. Since regulation is pretty stable over time, we use these data to measure regulation throughout the period covered by the GEM data (2001-2003).

${ }^{20}$ Other papers that have used these types of variables include de Melo, McKenzie, and Woodruff (2008) and Djankov et al. (2008).
} 
new business; the variable is equal to 0 otherwise. Finally, we measure social networks with the dummy variable Knowent, which is equal to 1 if an individual knows someone who has started a business in the past two years; the variable is equal to 0 otherwise. ${ }^{21}$

These variables vary substantially across countries and, particularly, according to countries' income levels. For example, both social networks and fear of failure are much lower in low-income countries than in high-income countries. Moreover, the proportion of individuals who are not working is substantially higher in low-income countries than in high-income countries. Similarly, the fraction of individuals with a college degree is much smaller in low-income countries than in other countries. In our data set, we also have information on the respondents' income. Given the importance of income for entrepreneurship, we report estimates with and without income dummies. Because the information about income is not always reported, we have to drop a sizable number of observations when we use income data. However, estimates across samples will provide some evidence of the robustness of our results.

In Table 2, we report the effects of individual characteristics and the interaction between individual characteristics and Entry regulation on the three indices of entrepreneurial activity, $T E A, T E A O P P, T E A N E C$. In Tables 3 and 4, we report the estimates for the other two measures of regulation: Contract and Labor. We first highlight some results about demographic variables. Consistent with other studies (Levesque and Minniti (2006), Hurst and Lusardi (2008)) we find a humpshaped profile for entrepreneurship in response to age changes; the probability of starting a new business increases until age 33 and decreases thereafter. Women are much less likely to become entrepreneurs, and this is the case for both opportunity and necessity entrepreneurship (Blanchflower (2004), Verheul, van Stel, and Thurik (2007)). One of the most noteworthy results of our estimates is the effect of education on entrepreneurship. Education is found to have no effect on the total measure of entrepreneurship. However, education has an effect on the type of entrepreneurship would-be entrepreneurs engage in. Specifically, those with a college degree are more likely to pursue opportunity entrepreneurship and less likely to pursue necessity entrepreneurship. Those with a high school education are also less likely to engage in necessity entrepreneurship. This is an important finding and can explain, for example, why previous studies have found different results on the effect of education on entrepreneurship; the effect on entrepreneurship depends very much on the measure of entrepreneurship one considers. Most importantly,

\footnotetext{
${ }^{21}$ Although we are aware that these variables may not be truly exogenous with respect to the choice of starting a new business, they can be critical indicators of the impediments or the stimulators of business creation and they can help explain the wide heterogeneity we see among business owners. Given our focus on regulation, we will not account for the potential endogeneity of these variables.
} 
this finding highlights why developing countries, where the population have low levels of educational attainment, display such high rates of entrepreneurship; however, many of these entrepreneurs are remedial/necessity entrepreneurs. Another important result is that both types of entrepreneurship - opportunity and necessity require some skills. Those who report having business skills are more likely to start a business. This again highlights one feature we think is not emphasized enough in the empirical work on entrepreneurs, i.e., the importance of skills. As discussed in detail in Koellinger, Minniti, and Schade (2007), self-perception of business skill is a critical determinant of entrepreneurship. According to our model as well, it is those who have more business skills who are more productive and therefore more likely to become entrepreneurs. Fear of failure also affects entrepreneurship, but the effect is concentrated on opportunity entrepreneurs only. This finding provides additional evidence that necessity entrepreneurs are rather different than opportunity entrepreneurs and that it is important to keep them distinct. Another important determinant of entrepreneurship is social networks, i.e., whether entrepreneurs know someone else who has started a business. Peer/network effects have been shown to be important for entrepreneurship and, in our sample as well, they are found to affect both opportunity and necessity entrepreneurs. ${ }^{22}$

As our model emphasizes, regulation can affect entrepreneurship via its effect on demographic characteristics. Starting with Entry, regulation dampens the negative effect of being a female (Table 2). However, this effect is only significant with regards to necessity entrepreneurship. Thus, women in more regulated countries are more likely to start a business because they cannot find better economic work. To assess the economic magnitude of this effect, we compare the effect of gender on entrepreneurship in low versus high regulation countries. In countries where entry regulation is at its lowest value $(R=0)$, women are 0.5 percentage points LESS likely to start a new business because they cannot find better work. But in countries where entry regulation is at its maximum value $(R=1)$, women will be 0.7 percentage points MORE likely to start a new business because they cannot find better work. Thus, regulation can pull women into business ownership, but not in order to pursue a business opportunity. This may explain why women are more likely to start smaller and less profitable businesses, even in developed countries (Coleman (2002)). Moreover, regulation accentuates the effect of not working. Those who are unemployed and do not currently work are less likely to start a business in countries where entry regulation is tighter.

Entry regulation also works through three other important determinants of entrepreneurship: social networks, business skills, and fear of failure. Entry regula-

\footnotetext{
${ }^{22}$ See Minniti (2005), Nanda and Sorensen (2008), Guiso and Schivardi (2007) and the references therein.
} 
tion dampens the effect of social networks; in countries with tighter entry regulation, knowing other entrepreneurs is shown to be less conducive to starting a new business. The effect is sizable. In countries with the highest level of entry regulation $(R=1)$, knowing other business owners increases the probability of starting a new business by 1.8 percentage points. Conversely, in countries where entry regulation is at its lowest level of zero $(R=0)$, knowing someone who has started a business in the recent past increases the probability of starting a new business by 5.3 percentage points. Thus, the effect is much increased with lower regulation. Moreover, the effect of regulation reduces sharply for the type of entrepreneurship we care about the most: opportunity entrepreneurship; the effect of social networks decreases from 3.7 to 1.3 percentage points. Similarly, entry regulation dampens the effect of business skills and again for opportunity entrepreneurship only: those who report having business skills are less likely to employ these skills to pursue a business opportunity. The effect is sizable. In countries in which regulation is at its highest levels, self-assessed skills increase the probability of becoming entrepreneurs to pursue a business opportunity by only 4 percentage points. That effect increases to 6.5 percentage points in countries with the lowest levels of entry regulation. Finally, entry regulation accentuates the effect of fear of failure among necessity entrepreneurs; when regulation is tighter, people who are more sensitive to the risk of failure are less likely to start a new business. Overall, the effects of entry regulation are detrimental to opportunity entrepreneurship. The findings reported above all speak against entry regulation.

Contract regulation has similar and sometimes even worse effects (Table 3). For example, the effect of contract regulation on women is stronger than the effect of Entry regulation. The effect now becomes significant for the total entrepreneurship index $T E A$, even though it is only necessity entrepreneurship that is affected. In other words, in countries with tighter contract regulation, women are more likely to pursue necessity entrepreneurship, i.e., to start a business because they can't find better work. In countries with the highest levels of contract regulation, women are 0.7 percentage points more likely to engage in necessity entrepreneurship as opposed to 0.4 percentage points more likely to do so in countries with the lowest levels of contract regulation. Also, in countries with tighter contract regulation, both students and the unemployed become less likely to pursue remedial entrepreneurial activity. As with entry regulation, contract regulation dampens the effect of social networks: in countries with tighter contract regulation, knowing other business owners is not as conducive to entrepreneurship, particularly opportunity entrepreneurship. In countries with the highest levels of contract regulation, those who know other business owners are only 1.9 percentage points more likely to engage in opportunity entrepreneurship as compared to 3.1 percentage points more likely in countries with the lowest levels of contract regulation. Importantly, con- 
tract regulation dampens the effect of business skills: in countries with the highest levels of contract regulation, those who report having business skills are less likely to engage in opportunity entrepreneurship. The likelihood of engaging in opportunity entrepreneurship is cut almost in half. In countries with the lowest levels of regulation, those who have business skills are 6.3 percentage points more likely to pursue a business opportunity; conversely in countries with the highest regulation, that figure reduces to 3.4 percentage points. Moreover, contract regulation exacerbates fear of failure and makes individuals less likely to pursue necessity entrepreneurship. Thus, contract regulation, similar to entry regulation, is a substantial deterrent to entrepreneurship.

Labor regulation also displays detrimental effects on entrepreneurship (Table 4). First, tighter labor regulation discourages entrepreneurship among older workers. Second, as in the other measures of regulation, labor regulation makes women more likely to become necessity entrepreneurs. In countries with the lowest levels of labor regulation, women are 0.4 percentage points less likely to start a business because they cannot find better work. In countries with the highest level of labor regulation, women are 0.3 percentage points more likely to engage in necessity entrepreneurship. Tighter labor regulation discourages entrepreneurship among those who do not work and among students, and for both necessity and opportunity entrepreneurship. Labor regulations dampen the effects of social network on opportunity entrepreneurship. In countries with the lowest levels of labor regulation, those who know other business owners are 3.7 percentage points more likely to start a new business to pursue a business opportunity. In countries with the highest labor regulation, those who know other business owners are only 1.4 percentage points more likely to engage in opportunity entrepreneurship. Finally, labor regulation accentuates fear of failure not only for necessity but also for opportunity entrepreneurship. Thus, even according to this third measure, which is rather different than the other two indices of regulation, regulation works against entrepreneurship.

These estimates confirm the findings of other papers. For example Van Stel, Storey, and Thurik (2007) use GEM data to examine the effect of business regulation on entrepreneurship. They use a different set of countries, a different time period, and different measures of regulation. Irrespective of these differences, their proxies of regulation, and specifically minimum capital requirements and labor market rigidity, are also found to have a negative effect on entrepreneurship. Aidis, Estrin, and Mickiewicz (2007) use GEM data and find that property rights are important for new businesses. ${ }^{23}$ Since their measure of property rights encompasses some regulatory constraints - such as freedom from government influence over the

\footnotetext{
${ }^{23}$ See also Aidis, Estrin, and Mickiewicz (2007) on the effect of institutions and networks in Russia.
} 
judicial system - and delays in receiving judicial decisions and/or enforcement that we used in the construction of our indices, they are not inconsistent with our results. Our estimates are also consistent with the work of Klapper, Laeven, and Rajan (2006) that shows that entry regulation represents an important barrier to entrepreneurship. Since they use a different definition of entrepreneurship, our results seem pretty robust. Ciccone and Papaioannou (2006) also find slower growth in expanding industries in countries where it takes longer to comply with procedures required to open a new firm. Rather than looking at entrepreneurship, Alesina, Ardagna, Nicoletti, and Schiantarelli (2005) look at investment and find that product market regulation is negatively related to investment, providing further evidence of the strength of our results.

Our results are robust to a variety of additional specification changes. First, when we control for dummy variables that capture the income level of the respondent, we find that the effects of regulation are very similar and even strengthen (Table 5). ${ }^{24}$ As the estimates for the income dummies make clear, necessity entrepreneurship is much more prevalent among individuals in the lower tail of the income distribution and less prevalent among individuals in the upper tail of the income distribution, and the extent of market regulation does not affect this result. On the contrary, the effect of income on the probability that an individual will start a business to pursue an opportunity depends on the regulatory environment. In countries that regulate entry and the labor market more heavily, would-be entrepreneurs are more likely to pursue a business opportunity if their incomes are in the upper tail of the distribution. Accounting for income does not change the estimates of the other determinants of entrepreneurship, nor the detrimental effect of regulation on entrepreneurship; the negative effects of regulation continue to hold even after accounting for income.

Second, we have estimated the model for 2001 and 2002 only (see Ardagna and Lusardi (2008a)). Results are very similar, but the inclusion of one additional year of data makes the results stronger. We have also estimated the model separately for each year. ${ }^{25}$ Results do not change substantially.

Third, we interact the components of each synthetic index of regulation with the vector of individual characteristics to investigate whether a particular aspect of

\footnotetext{
${ }^{24}$ The income distribution of each country is divided into three groups: low, middle and high income (each including 33\% of the population). Given his income, each respondent is then classified as belonging to a specific income group. The income dummies Lowestinc and Upperinc included in Table 4 are equal to 1 if an individual's income is in the lowest or upper third, respectively, of the income percentile of his country's income distribution, and equal to 0 otherwise.

${ }^{25}$ Data for Portugal are not available in 2002. Data for Switzerland, Chile, Thailand, China, Taiwan, Hong Kong, Croatia, and Slovenia are not available in 2001. Data for Greece, Uganda, and Venezuela are available only for 2003.
} 
regulation is driving the results reported in Tables 2-5. We find that the components of the indices generally have similar effects on entrepreneurship even though some components have a larger and more significant effect through some personal characteristics' variables than through others. ${ }^{26}$

Finally, we examine whether our results hinge on data for a particular country. We exclude one country at a time and reestimate the specification used in Tables 2-5. Results are qualitatively the same, even when excluding Russia, Poland, and Slovenia, whose data seem to be of poorer quality. ${ }^{27}$

\subsection{Entrepreneurship and regulation: Evidence from the Flash Euro- barometer}

In this section, we estimate the regressions in Tables 2-4 using data from the Flash Eurobarometer. The reason for this additional empirical analysis is twofold. First, the estimates act as a robustness check on the quality of GEM data and the results discussed so far. Second, and more importantly, using the Flash Eurobarometer data, we can exploit the time variation of the regulatory indices ${ }^{28}$ and we are able to investigate not only the indirect effect that regulation has on entrepreneurship via its impact on the return of individual characteristics but also its direct effect. Hence, we can estimate the coefficient $\beta_{3}$ in equation (11) above, assess the total effect of regulation on entrepreneurship, and provide a more thorough empirical test of our model.

Table 6 shows the results. First, the estimates of the effect of individual characteristics on the likelihood of starting a new business are similar to those presented in Tables 2-4. For example, we find a hump-shaped profile for entrepreneurship in response to age changes. Women are much less likely to become entrepreneurs and this is the case for both opportunity and necessity entrepreneurship. Fear of going bankrupt negatively affects entrepreneurship and, as in the regressions in Tables $2-4$, the effect is concentrated mostly on opportunity entrepreneurs. Finally, an individual's social networks, measured in Table 6 with a dummy variable equal to 1 if at least one of the respondent's parents is self-employed, are a very important determinant of entrepreneurship. Once again, it is particularly so for opportunity entrepreneurs. Second, we find no robust evidence of a direct effect of regulation on entrepreneurship. The coefficients of the regulatory indicators are not statistically significant except in one case. In column (6) the coefficient of the contract

\footnotetext{
${ }^{26}$ For brevity, estimates are not reported but are available upon request.

${ }^{27}$ Estimates are not reported but are available from the authors.

${ }^{28}$ We use the 2003 and the 2006 Doing Business Database and match the regulatory indicators for 2003 with the 2004 Flash Eurobarometer data and the regulatory indicators for 2006 with the 2007 Flash Eurobarometer data.
} 
regulation variable is positive and statistically significant at the $5 \%$ level, implying that in countries with tighter contract regulation, individuals are more likely to pursue necessity entrepreneurship. Third, regulation affects entrepreneurship via its effect on some individual characteristics. As before, regulation dampens the negative effect of being a female and this effect is only significant for necessity entrepreneurship. Hence, women in more regulated countries are more likely to start a business because they cannot find better economic work. Also, regulation dampens the effect of social networks: in countries with tighter entry, contract, and labor market regulation, having at least one self-employed parent has a positive but lower effect on the likelihood of starting a new business than it does in less regulated countries.

Finally, the effects of education on entrepreneurship are weaker, but overall consistent with the results shown so far. ${ }^{29}$ In fact, the coefficients of the variables HighSchool and College are not always statistically significant. However, the interaction terms of the education dummies and the regulatory indicators are significant in many specifications. Specifically, the interaction terms of the education dummies and the indicator of entry regulation are significant and their sign and magnitude imply that those with a college degree are more likely to pursue opportunity entrepreneurship and less likely to pursue necessity entrepreneurship. Those with a high school education are also more likely to engage in opportunity entrepreneurship. These effects are stronger in more regulated countries. Hence, the probability that an individual with at least a high school degree will start a new business because of an opportunity (necessity) increases (decreases) with entry regulation, signaling that education is extremely important to overcoming the barriers introduced by entry regulation. Similarly, individuals with at least a high school or college degree are less likely to engage in necessity entrepreneurship, more so in countries with more pervasive regulation of labor markets.

\subsection{Instrumental variables estimation}

Even though regulation often results from laws enacted in the distant past, one may worry that it is the level of entrepreneurship that affects regulation in a country. In other words, while our theoretical model does not discuss this possibility, in fact the causality between entrepreneurship and regulation may go the opposite way. Moreover, it could be that unobservables that drive entrepreneurship in a country (e.g., an educational system that encourages individual responsibility or

\footnotetext{
${ }^{29}$ The dummy variables that measure whether an individual has a high school and/or a college degree are proxied with some error. In fact, the Flash Eurobarometer Surveys ask each respondent the age at which he/she completed full-time education but not the degree obtained. Appendix IV describes how we computed the dummy variables included in the regression.
} 
an extensive welfare system that insulates against unemployment and health risks) also drive the regulatory system in that country. Thus, the relationship between entrepreneurship and regulation may simply be the result of these omitted variables. This problem may be less relevant in our empirical work since we also look at the interaction of regulation with individual characteristics rather than simply looking at the effect of regulation on entrepreneurship. Nevertheless, we tackle these considerations by resorting to a different estimation strategy: instrumental variables (IV) estimation.

We use countries' legal origins as instruments. Several papers have shown that current regulatory environments correlate with countries' legal traditions. ${ }^{30}$ For example, as illustrated in Figure 1, countries of English legal origin are among those with low levels of regulation, while countries of French and Socialist legal origin are more heavily regulated. Because countries' legal origins are the result of conquest and colonization that occurred centuries ago, legal origin is unlikely to be correlated with omitted variables that influence individuals' decisions to begin a new entrepreneurial activity in the twenty-first century.

As in Figure 1, we group countries with English (common law), French (civil law), Socialist, German, and Scandinavian legal origins. We estimate equation (11) instrumenting the variable $R$ with the indicator variables that measure countries' legal origins. Results are reported in Table 7 . Note that coefficient estimates are included in Table 7, while marginal effects are reported in all the other tables of the paper; hence, the numbers in the tables are not directly comparable. The estimates continue to confirm the results reported in Tables 2-5. Regulation acts as a deterrent to entrepreneurship by curbing the effects of several important determinants of entrepreneurship. For example, entry regulation curbs the effect of having a college degree, of social networks, and of having business skills, and accentuates the effect of fear of failure. Contract regulation also curbs the effects of college education, social networks, and business skills, primarily for opportunity entrepreneurs. Labor regulation again curbs the effects of social networks and accentuates the effects of fear of failure. Note that the p-value of a Wald test on the exogeneity of the regressors does not reject exogeneity. Thus, the estimates reported in Tables 2-4 do not seem to be biased due to a potential endogeneity problem.

We also check whether the estimates obtained using the Flash Eurobarometer data are robust to instrumenting regulation with countries' legal origins. Even though the effect of regulation via its effect on the return of some personal characteristics is somewhat smaller, the IV results (not shown but available upon request) are in general consistent with the ones shown in Table $6 .{ }^{31}$

\footnotetext{
${ }^{30}$ See La Porta et al. (1998, 2000).

${ }^{31}$ Note that when we instrument regulation with countries' legal origins, we are not able to estimate
} 


\section{Discussion}

The estimates reported above illustrate that regulation is a major deterrent to entrepreneurship. Not only does tighter regulation dampen the effects of important predictors of entrepreneurship, such as social networks and business skills, but it also curbs opportunity entrepreneurship, which is the type of entrepreneurship that matters the most in terms of employment and growth. While several authors have proposed policies to encourage entrepreneurship that focus mostly on relaxing liquidity constraints, in this paper we highlight another way in which countries can foster entrepreneurship: relax regulation. According to our estimates, adopting the policies of low-regulation countries can substantially spur the birth of new businesses. Easing of regulation will allow individuals who have business skills to try out new ventures and will exploit the synergies offered by interactions with other entrepreneurs. Moreover, entrepreneurs will be pulled into the type of entrepreneurship that can be more beneficial for both the macro economy and individual well-being.

As our estimation method clearly highlights, the effects of regulation tend to concentrate on specific groups. For example, in more heavily regulated countries, women, who are already less likely to become entrepreneurs, are more likely to be pulled into necessity/remedial entrepreneurship. This suggests that policies to foster entrepreneurship among women could be strenghtened simply by a decrease in regulatory constraints. Similarly, those who do not currently work are harmed by tighter regulation. Since these are already vulnerable groups, regulation can end up having truly harmful effects.

Our estimates also point to some alternative ways in which entrepreneurship can be supported. First, according to the estimates reported in Tables 2-6, policies that support and foster education also foster entrepreneurship. Increasing education attainment can achieve three important objectives: fostering entrepreneurship, encouraging would-be entrepreneurs into pursuing business opportunity, and discouraging necessity entrepreneurship. Very few policies can hit multiple targets in such a way. Related to education, our estimates also indicate that those who have business skills are more likely to enter entrepreneurship. Thus, teaching or fostering such skills in schools or in training programs may be another way to foster entrepreneurship. ${ }^{32}$ Peers and social networks are also important for entrepreneur-

the direct effect of regulation even with the Flash Eurobarometer data. Our instruments are time invariant, and, hence, we cannot separately estimate the coefficients of the country dummies and the regulatory indicators.

${ }^{32}$ The paper by Klinger and Schundeln (2007) studies a business training program that an NGO held in Central America between 2002 and 2005 and shows that entrepreneurial activity can be fostered by training. In fact, receiving business training increases the likelihood of starting a new 
ship. Therefore, encouraging or creating business clusters could also jump-start entrepreneurship.

\section{Conclusions}

In this paper, we have used two micro data sets measuring entrepreneurship across countries to examine the effects of regulation. One major advantage of using these data sets is the possibility of distinguishing between two distinct types of entrepreneurs: those who intend to pursue a business opportunity and those who could not find better economic work. Because entrepreneurship usually mixes different activities, not all of which should be promoted, it is critically important to be able to differentiate between entrepreneurial types.

Irrespective of the measure of regulation we use, we always find that regulation is a detriment to entrepreneurial activity. In more heavily regulated countries, those who have business skills, know other entrepreneurs, have less fear of failure, and do not work are less likely to engage in entrepreneurship. Moreover, in countries with higher regulation, vulnerable groups, such as women and those who do not work, are more likely to be pulled into necessity entrepreneurship.

This is one of the few studies that performs a micro analysis of the determinants of entrepreneurship and the effects of regulation from two data sets on a large cross section of countries. We plan to expand this work further and examine in more detail the two tails of entrepreneurship.

\section{References}

[1] Ac, Z., S. Desai, Klapper L. (2007), "What Does "Entrepreneurship" Data Really Show? A Comparison of the Global Entrepreneurship Monitor and World Bank Group Datasets,” mimeo.

[2] Aghion, P., P. Howitt (1997), "Endogenous Growth Theory,” Cambridge, MA, MIT Press, 1997.

[3] Alesina A., S. Ardagna, G. Nicoletti, and F. Schiantarelli, (2005), "Regulation and Investment,” Journal of the European Economic Association, 3(4), pp. 791-825.

business or expanding an existent one. 
[4] Ai, C., E. Norton (2003), "Interaction Terms in Logit and Probit Models", Economic Letters, n.80, pp. 123-129.

[5] Aidis, R., S. Estrin and T. Mickiewicz (2007), "Entrepreneurship in Emerging Markets: Which Institutions Matter?," Working Paper n. 81, Center for the Study of Economic and Social Changes in Europe, University College London.

[6] Alfaro, L., A. Charlton (2007), "International Financial Integration and Entrepreneurial Firm Dynamics,” Harvard Business School Working Paper, n. 07-012

[7] Ardagna, S. and A. Lusardi (2008a), “Explaining International Differences in Entrepreneurship: The Role of Individual Characteristics and Regulatory Constraints”, NBER working paper 14012.

[8] Ardagna, S. and A. Lusardi (2008b), “The Two Tails of Entrepreneurship,” mimeo, Harvard University.

[9] Banerjee, A., A. Newman (1994), "Poverty, Incentives, and Development," American Economic Review Papers and Proceedings, vol. 84, pp. 211-215.

[10] Bassanini, A. and E. Ernst (2002). "Labor Market Institutions, Product Market Regulations and Innovation: Cross Country Evidence,” OECD Economics Department Working Papers, No. 316.

[11] Bayoumi, T., D. Laxton, P. Pesenti (2004), "Benefits and Spillovers of Greater Competition in Europe: a Macroeconomic Assessment,” Federal Reserve Bank of New York Staff Report 182.

[12] Bertrand, M. and F. Kramarz (2002). "Does Entry Regulation Hinder Job Creation? Evidence From The French Retail Industry,” Quarterly Journal of Economics, pp. 1369-1413.

[13] Blanchflower, D. (2004), "Self-Employment: More May Not Be Better," Swedish Economic Policy Review, vol 11(2), pp. 15-74.

[14] Blanchflower, D. (2000), "Self-Employment in OECD Countries," Labour Economics, 7, pp. 471-505.

[15] Blanchflower, D., A. Oswald, and A.Stutzer (2001), "Latent Entrepreneurship Across Nations,” European Economic Review, 45(4-6), pp. 680-691.

[16] Blanchflower, D., A. Oswald (1998), “What Makes an Entrepreneur?,” Journal of Labor Economics, 16(1), pp. 26-60, 1998. 
[17] Blanchard, O. J. and J. Wolfers (2000). "The Role of Shocks and Institutions in the Rise of European Unemployment: The Aggregate Evidence," Economic Journal, 110, pp. 1-33.

[18] Ciccone, A. and E. Papaioannou (2006), "Red tape and Delayed Entry," CEPR Discussion Paper n 5996.

[19] Coleman, S. (2002), “Constraints Faced by Women Small Business Owners: Evidence from the Data.” Journal of Developmental Entrepreneurship, vol. 7, pp. 151-174.

[20] de Melo S, D. McKenzie, and C. Woodruff (2008), "Who Are the Microenterprise Owners? Evidence from Sri Lanka on Tokman v. de Soto, forthcoming in J. Lerner and A. Schoar (eds.), "International Differences in Entrepreneurship."

[21] Desai, M., P. Gompers and J. Lerner (2003), "Institutions, Capital Constraints and Entrepreneurial Firm Dynamics: Evidence from Europe,” NBER Working Paper No. 10165.

[22] Djankov, S., Y. Qian, G. Roland, and E. Zhuravskaya (2008), "What Makes an Entrepreneur?,” mimeo.

[23] Djankov, S., T. Ganser, C. McLiesh, R. Ramalho, A. Shleifer (2007), The Effect of Corporate Taxes on Investment adn Entrepreneurship,” mimeo.

[24] Djankov, S., Y. Qian, G. Roland, and E. Zhuravskaya (2006a), "Who are China's Entrepreneurs?,” American Economic Review, Papers and Proceedings, vol. 96, pp. 348-352.

[25] Djankov, S., Y. Qian, G. Roland, and E. Zhuravskaya (2006b), "Entrepreneurship in China and Russia Compared," Journal of the European Economic Association, vol. 4, n. 2-3, pp. 352-365.

[26] Djankov, S., Y. Qian, G. Roland, and E. Zhuravskaya (2005), “Who are Russia's Entrepreneurs?,” Journal of the European Economic Association, vol. 3, n. 2-3, pp. 1-11.

[27] Djankov, S., R. La Porta, Lopez-De-Silanes F., and A. Shleifer (2004), “The Regulation of Labor,” Quarterly Journal of Economics, pp. 1339-1381.

[28] Djankov, S., R. La Porta, Lopez-De-Silanes F., and A. Shleifer (2003), “Courts," Quarterly Journal of Economics, pp. 453-517. 
[29] Djankov, S., R. La Porta, Lopez-De-Silanes F., and A. Shleifer (2002), “The Regulation of Entry,” Quarterly Journal of Economics, pp. 1-37.

[30] Evans, D., and B. Jovanovic (1989), “An Estimated Model of Entrepreneurial Choice Under Liquidity Constraints,” Journal of Political Economy, vol. 97, no. 4, pp. 808-827.

[31] Fairlie, R., and A. Robb (2007), "Why Are Black-Owned Businesses Less Successful than White-Owned Businesses? The Role of Families, Inheritances, and Business Human Capital,” Journal of Labor Economics, 25(2), pp. 289-323.

[32] Fiori, G.,G. Nicoletti, S. Scarpetta, and F. Schiantarelli (2007), “Employment Outcomes and the Interaction Between Product and Labor Market Deregulation: Are They Substitutes or Complements?,” Boston College Working Papers in Economics 663.

[33] Gentry, W., R. G. Hubbard (2000), “Tax Policy and Entrepreneurial Entry,” American Economic Review Papers and Proceedings, vol. 90, no. 2, pp. 283287.

[34] Guiso, L., and F. Schivardi (2007),"What Determines Entrepreneurial Clusters?,” mimeo.

[35] Guiso L., P. Sapienza, and L. Zingales (2004), "Does Local Financial Development Matter?,” Quarterly Journal of Economics, pp. 929-969.

[36] Hurst E., and A. Lusardi (2004), "Liquidity Constraints, Household Wealth, and Entrepreneurship,” Journal of Political Economy, vol. 112(2), pp. 319347.

[37] Hurst E., and A. Lusardi (2008), “Liquidity Constraints and Entrepreneurship. Household Wealth, Parental Wealth, and the Transition In and Out of Entrepreneurship", in D. Furchtgott-Roth (ed.), "Overcoming Barriers to Entrepreneurship," Lexington Books, MD: Lanham, pp. 47-68.

[38] Klinger B., and M.Schündeln (2007), “Can Entrepreneurial Activity be Taught? Quasi-Experimental Evidence from Central America”, Center for International Development Working Paper No. 153 December 2007.

[39] Klapper L., L. Laeven, and R. Rajan, (2006) ,"Entry Regulation as a Barrier to Entrepreneurship,” Journal of Financial Economics (forthcoming). 
[40] Koellinger, P., M. Minniti and C. Schade (2007), "'I think I can, I think I can": Overconfidence and Entrepreneurial Behavior," Journal of Economic Psychology, 28, pp. 502-527.

[41] La Porta R., F. Lopez-de-Silanes, A. Shleifer, and R. W. Vishny (2000), "Investor Protection and Corporate Governance," Journal of Financial Economics, vol. 58, pp. 1-25.

[42] La Porta R., F. Lopez-de-Silanes, A. Shleifer, R. W. Vishny, (1998), "Law and Finance,” Journal of Political Economy, vol. 106, pp.1113-1155.

[43] Levesque M. and M. Minniti (2006), "The Effect of Aging on Entrepreneurial Behavior," Journal of Business Venturing, 21, pp. 177-194.

[44] Loayza N., A. Oviedo, Serven L., (2004), "Regulation and Macroeconomic Performance,” World Bank Policy Research Working Papers n. 3469.

[45] Lucas R., (1978), “On the SIze of Distribution of Business Firms”, The Bell Journal of Economics, vol. 9, no. 2, pp 508-523.

[46] Malesky E., M. Taussig, (2008), Out of the Gray: The Impact of Institutions on Business Formalization in an Emerging Market, mimeo.

[47] Minniti, M. (2005), "Entrepreneurship and Network Externalities," Journal of Economic Behavior and Organization, 57, pp 1-27.

[48] Mondragon-Velez, C. and X. Pena-Parga, (2008), "Business Ownership and Self-Employment in Developing Economies: The Colombian Case," forthcoming in J. Lerner and A. Schoar (eds), "International Differences in Entrepreneurship."

[49] Mullainathan, S. and P. Schnabl (2008), "Business Simplification in Peru," forthcoming in J. Lerner and A. Schoar (eds), "International Differences in Entrepreneurship."

[50] Nanda R., and J. B. Sorensen (2007), "Peer Effects and Entrepreneurship," Harvard Business School Working Paper n. 08-051.

[51] Nicoletti, G., and S. Scarpetta (2003), "Regulation, Productivity, and Growth: OECD Evidence,” Economic Policy, vol. 18, no. 36, pp.11-72.

[52] Norton E. H. Wang, and C. Ai (2004), “Computing Interaction Effects and Standard Errors in Logit and Probit Models”, The Stata Journal 2004, 4, n.2, pp. 154-167. 
[53] Puri M., D. and T. Robinson (2006), "Who Are Entrepreneurs and Why Do They Behave That Way,” Working Paper Duke University.

[54] Reynonds P., N. Bosma, E. Autio, S. Hunt, N. De Bono, I. Servais, P. LopezGarcia, and N. Chin (2005), "Gobal Entrepreneurship Monitor: Data Collection Design and Implementation 1998-2003,” Small Business Economics, vol. 24, pp. 205-231.

[55] Van Stel A., D. Storey and R. Thurik (2007), "The Effect of Business Regulation on Nascent and Young Business Entrepreneurship," Small Business Economics, 28, pp. 171-186.

[56] Verheul, I., A. van Stel and R. Thurik (2006), "Explaining Female and Male Entrepreneurship across 29 Countries," Entrepreneurship and Regional Development, 18, pp. 151-183. 


\title{
Appendix I: Variables used in the empirical analysis
}

\author{
Entrepreneurship indices. Source: Global Entrepreneurship Monitor
}

- $T E A=1$ if individuals are starting a new business or are owners and managers of a young firm; 0 otherwise.

- $T E A O P P=1$ if individuals are starting a new business or are owners and managers of a young firm to take advantage of a business opportunity; 0 otherwise.

- $T E A N E C=1$ if individuals are starting a new business or are owners and managers of a young firm because they could find no better economic work, 0 otherwise.

Individuals' characteristics. Source: Global Entrepreneurship Monitor

- $A G E=$ age of the individual at the time of the interview.

- $M A L E=1$ if male; 0 otherwise.

- WORK ING = 1 if individual works at the time of the interview; 0 otherwise.

- $S T U D E N T S=1$ if individual is a student at the time of the interview; 0 otherwise.

- RET I RED DISABLED = 1 if individual is retired or disabled at the time of the interview; 0 otherwise.

- NOTWORKING = 1 if individual does not work (and he/she is not a student nor a retired or disabled individual) at the time of the interview; 0 otherwise.

- HIGHSCHOOL = 1 if individual has a high school degree; 0 otherwise.

- $C O L L E G E=1$ if individual has at least a college degree; 0 otherwise.

- KNOWENT = 1 if the person knows someone who has started a business in the recent past; 0 otherwise.

- $S K I L L S=1$ if the person thinks he or she has the knowledge, skills, and experience to start a new business; 0 otherwise. 
- FEARFAIL $=1$ if the person's fear of failing can prevent him or her from starting a new business; 0 otherwise.

- LOWEST INC = 1 if individual's income is in the lowest 33rd income percentile of his country's income distribution; 0 otherwise.

- UPPERINC = 1 if individual's income is in the upper 33rd income percentile of his country's income distribution; 0 otherwise.

Regulatory Indices. Various sources

- ENTRY measures the barriers and costs entrepreneurs face when they decide to create a new business; $E N T R Y=$ (procedures + time + cost + regulation $) / 4$.

- $P R O C E D U R E S$ = number of procedures that are officially required to start and operate a new business. Source: Doing Business Database (The World Bank Group), 2003.

- $T$ I ME = time in calendar days needed to complete procedures that are officially required to start and operate a new business. Source: Doing Business Database (The World Bank Group), 2003.

- $\operatorname{COST}=$ cost (measured as a percentage of the country's income per capita) needed to complete procedures that are officially required to start and operate a new business. Source: Doing Business Database (The World Bank Group), 2003.

- REGULAT I ON (IE F) = composite index measuring not only how easy/difficult it is to operate a business but also examining the degree of corruption in the government and whether or not regulation is applied uniformly to all businesses. Source: Index of Economic Freedom (The Heritage Foundation), variable name in IEF database: regulation, average 1995-2000.

- CONTRACT measures the efficiency of the justice system in resolving commercial disputes; CONTRACT = (procedures + quality of bureaucracy)/2.

- $P R O C E D U R E S$ = number of procedures required to solve a dispute. Source: Doing Business Database (The World Bank Group), 2003.

- $Q U A L I T Y$ OF BURE AUCRACY = index measuring the ability of the government to operate without dramatic changes in policy or interruptions of its services. Source: International Country Risk Guide (The PRS Group); variable name in ICRG database: bureaucracy, average 1984-2000. 
- $L A B O R$ measures the difficulty for entrepreneurs of adjusting the labor force. $L A B O R=$ (hiring index + firing index + firing costs + rigidity of labor contracts + union density)/5.

- H I RI NG I NDEX = index measuring the availability of term contracts for temporary/permanent task, the maximum cumulative duration of term contracts, and the ratio of the minimum wage for a trainee or first-time employee to the average value added per worker. Source: Doing Business Database (The World Bank Group), 2003.

- FI RING I NDEX = index measuring whether redundancy is disallowed as a basis to fire a worker; the need for the employer to notify a third party and/or to get approval from a third party when firing one redundant worker and/or a group of more than 20 redundant workers; whether the law requires the employer to consider retraining or reassignment before firing a redundant worker; whether priority rules apply for redundancies and reemployment. Source: Doing Business Database (The World Bank Group), 2003.

- FIRING COST = index measuring the cost in weekly wages of advance notice requirements, severance payments and penalties due when terminating a redundant worker. Source: Doing Business Database (The World Bank Group), 2003.

- RIGIDITY LABOR CONTRACT S = index measuring whether night and/or weekend work is unrestricted, whether the workweek can consist of 5.5 days and/or can be extended to 50 hours or more (including overtime) for 2 months a year, whether paid annual vacation is 21 working days or fewer. Source: Doing Business Database (The World Bank Group), 2003.

- UNION DENSITY = percentage of total workforce affiliated with labor unions in 1997. Source: Djankov et al. (2004).

Countries' groups

- LOW I NCOME includes India. Source: World Bank’s classification, see www.worldbank.org/data/countryclass/classgroups.htm.

- MIDDLE LOWINC includes Brazil, China, Thailand. Source: World Bank’s classification, see www.worldbank.org/data/countryclass/classgroups.htm.

- UPPER MIDDLE INC includes Argentina, Chile, Croatia, Hungary, Mexico, Poland, Russia, South Africa. Source: World Bank’s classification, see www.worldbank.org/data/countryclass/classgroups.htm. 
- HIGH INCOME includes Australia, Belgium, Canada, Denmark, Finland, France, Germany, Hong Kong, Ireland, Israel, Italy, Japan, the Netherlands, Norway, New Zealand, Portugal, Singapore, Slovenia, Spain, South Korea, Sweden, Switzerland, Taiwan, United Kingdom, United States. Source: World Bank's classification, see www.worldbank.org/data/countryclass/classgroups.htm.

- OECD includes Australia, Belgium, Canada, Denmark, Finland, France, Germany, Ireland, Italy, Japan, the Netherlands, Norway, New Zealand, Portugal, Spain, Sweden, Switzerland, United Kingdom, United States.

- EU includes Belgium, Denmark, Finland, France, Germany, Ireland, Italy, The Netherlands, Portugal, Spain, Sweden, United Kingdom.

- EC A includes Croatia, Hungary, Poland, Russia, Slovenia.

- EAP includes China, Hong Kong, Singapore, South Korea, Taiwan, Thailand.

- L AT I N AME RIC A includes Argentina, Brazil, Chile, Mexico.

\section{Legal Origin}

- ENGL ISH includes Australia, Canada, Hong Kong, India, Ireland, Israel, New Zealand, South Africa, Singapore, Thailand, United Kingdom, United States. Source: Djankov et al. (2003).

- SOCI AL I ST includes China, Croatia, Hungary, Poland, Russia, Slovenia. Source: Djankov et al. (2003).

- FRENCH includes Argentina, Belgium, Brazil, Chile, France, Italy, Mexico, the Netherlands, Portugal, Spain. Source: Djankov et al. (2003).

- GE RMAN includes Germany, Japan, Switzerland, South Korea, Taiwan. Source: Djankov et al. (2003).

- SC AN DI N AV I AN includes Denmark, Finland, Norway, Sweden. Source: Djankov et al. (2003). 


\section{Appendix II: GEM survey questions}

The following are the questions that the GEM coordination team uses to generate the variables $T E A, T E A O P P, T E A N E C$. Questions are from the 2002 data documentation manual. Questions asked in 2001 were exactly the same, even though the numbering of the questions changed. The methodology followed to construct the indices is based on procedures previously used in the U.S. Panel Study of Entrepreneurial Dynamics, and it is described in detail in the 2001 and 2002 Adult Population Survey data documentation and in Reynolds et al. (2005).

- 1. Which of the following would apply to you? (Possible answers: Yes, No, Don't Know, Refused)

- 1a. You are, alone or with others, currently trying to start a new business, including any self-employment or selling any goods or services to others.

- 1b. You are, alone or with others, currently trying to start a new business or a new venture for your employer, an effort that is part of your normal work.

- 1c. You are, alone or with others, currently the owner of a company you help manage, self-employed, or selling any goods or services to others.

- If "Yes", Or “Don’t Know” To Qu. 1a or Qu. 1b, Ask Qu 2a. If “Yes”, Or “Don’t Know” To Qu. 1c, Ask Qu. 3a.

- 2a. Over the past twelve months, have you done anything to help start a new business, such as looking for equipment or a location, organizing a start-up team, working on a business plan, beginning to save money, or any other activity that would help launch a business?

- 2b. Will you personally own all, part, or none of this business?

- 2d. Has the new business paid any salaries, wages, or payments in kind, including your own, for more than three months?

- $2 \mathrm{~d} 1$. What was the first year the owners received wages, profits, or payments in kind?

- 2g. Are you involved in this start-up to take advantage of a business opportunity or because you have no better choices for work?

- 3a. Do you personally own all, part, or none of this business? 
- 3c. What was the first year the owners received wages, profits, or payments in kind? Payments in kind refers to goods or services provided as payments for work rather than cash. ${ }^{33}$

- 3g. Are you involved in this firm to take advantage of a business opportunity or because you have no better choices for work?

The following are the survey questions used to define the variables Knowent, Skills, and Fear fail, respectively. Questions are from the 2002 data documentation manual. Questions asked in 2001 were exactly the same even though the numbering of the questions changed.

- 1. Which of the following would apply to you? (Possible answers: Yes, No, Don't Know, Refused)

- 1g. You know someone personally who started a business in the past two years.

- 1i. You have the knowledge, skill, and experience required to start a new business.

- $1 \mathrm{j}$. Fear of failure would prevent you from starting a business.

\footnotetext{
${ }^{33}$ From this question, researchers can identify owners who have received wages, profits, or payments in kind for no more than 42 months.
} 


\section{Appendix III: Flash Eurobarometer Surveys}

The survey questions of the Flash Eurobarometer Surveys used to generate the variables $T E A, T E A O P P, T E A N E C$ in Table 7 are the following:

- 1) Have you started a business recently or are you taking steps to start a new one? (Possible answers: a) It never came to your mind. b) No, but you are thinking about it. c) No, you thought of it and you had already taken steps to start a business but gave up. d) Yes, you are currently taking steps to start a new business. e) Yes, you have started or taken over a business in the last three years which is still active today. f) Yes, you started or took over a business more than three years ago and it is still active. g) No, you once started a business, but currently you are no longer an entrepreneur (business has failed, business was sold, or the interviewee has retired). h) Don’t Know).

- 2) All in all, would you say you started, or are starting, your business because you saw an opportunity or you started it out of necessity? (Possible answers: a) You started it because you came across an opportunity. b) You started it because it was a necessity. c) Both. d) Don’t Know).

The variables TE A, T E AO P P, TE ANEC in Table 7 are defined as follows:

- $T E A=1$ if individuals replied "Yes, you are currently taking steps to start a new business" or "Yes, you have started or taken over a business in the last three years which is still active today" to question 1 above; 0 otherwise.

- $T E A O P P=1$ if individuals replied "Yes, you are currently taking steps to start a new business" or "Yes, you have started or taken over a business in the last three years which is still active today" to question 1 above and individuals replied "You started it because you came across an opportunity" to question 2 above; 0 otherwise.

- $T E A N E C=1$ if individuals replied "Yes, you are currently taking steps to start a new business" or "Yes, you have started or taken over a business in the last three years which is still active today" to question 1 above and individuals replied "You started it because it was a necessity" to question 2 above; 0 otherwise. 


\begin{tabular}{|c|c|c|c|c|}
\hline & \multicolumn{2}{|c|}{$\begin{array}{c}\text { EMPLOYMENT AT TIME OF SURVEY } \\
(1) \\
\text { TEAOPP }\end{array}$} & $\begin{array}{c}\text { EXPECTED E } \\
\text { (3) } \\
\text { TEAOPP }\end{array}$ & $\begin{array}{l}\text { TT IN } 5 \text { YEARS } \\
\text { (4) } \\
\text { TEANEC }\end{array}$ \\
\hline $10^{\mathrm{TH}}$ Percentile & 0 & 0 & 0 & 0 \\
\hline $25^{\mathrm{TH}}$ Percentile & 0 & 0 & 2 & 1 \\
\hline $50^{\mathrm{TH}}$ PERCENTILE & 2 & 1 & 4 & 2 \\
\hline $75^{\mathrm{TH}}$ Percentile & 5 & 3 & 10 & 6 \\
\hline $90^{\mathrm{TH}}$ Percentile & 12 & 6 & 30 & 15 \\
\hline $95^{\mathrm{TH}}$ Percentile & 24 & 10 & 60 & 25 \\
\hline $99^{\mathrm{TH}}$ PERCENTILE & 150 & 50 & 500 & 150 \\
\hline 99.5 ${ }^{\mathrm{TH}}$ PERCENTILE & 500 & 133 & 1100 & 400 \\
\hline
\end{tabular}

Notes: Average number of jobs created, or expected to be created in five years, at different points of the employment distribution. TEAOPP = 1 if individuals are starting a new business or are owners and managers of a young firm to take advantage of a business opportunity, 0 otherwise; TEANEC $=1$ if individuals are starting a new business or are owners and managers of a young firm because they could find no better economic work, 0 otherwise. See Appendix I and Appendix II for the exact definition of the variables. 
Table 2: Entrepreneurship and regulation of entry

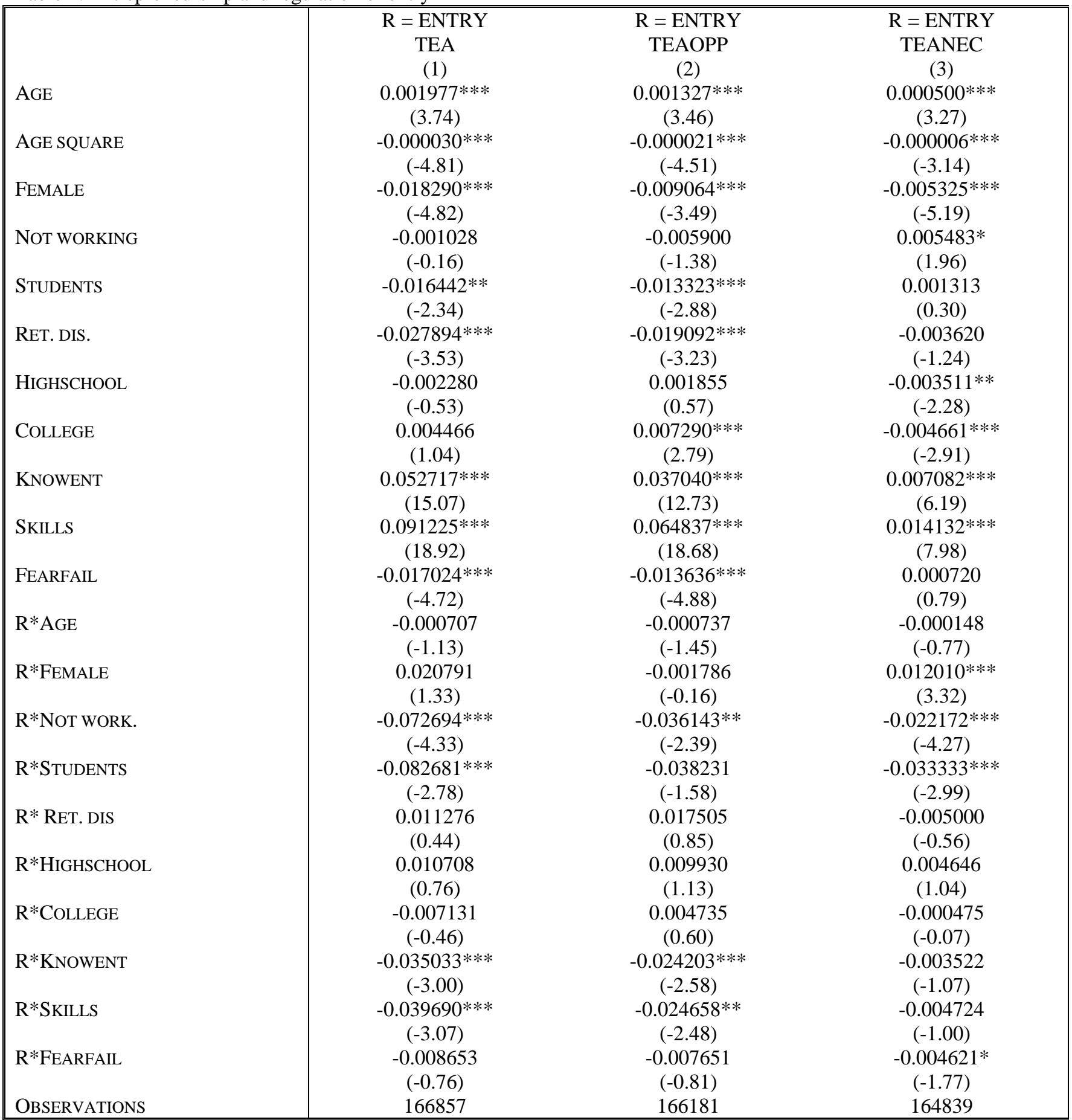

Notes: Probit regressions including country fixed effects and time dummies. Standard errors are clustered at the country level. Marginal effects (not coefficients) and t-stat. are shown in the tables. ${ }^{* * *}$, **, $*$ coefficients statistically significant at $1 \%, 5 \%$, and $10 \%$ level, respectively. TEA $=1$ if individuals are starting a new business or are owners and managers of a young firm, 0 otherwise; TEAOPP $=1$ if individuals are starting a new business or are owners and managers of a young firm to take advantage of a business opportunity, 0 otherwise; TEANEC $=1$ if individuals are starting a new business or are owners and managers of a young firm because they could find no better economic work, 0 otherwise; ENTRY measures the barriers and costs entrepreneurs face when they decide to create a new business; ENTRY $=$ (procedures + time + cost + regulation (IEF))/4. See Appendix I and Appendix II for the exact definition of the variables. 
Table 3: Entrepreneurship and contract enforcement regulation

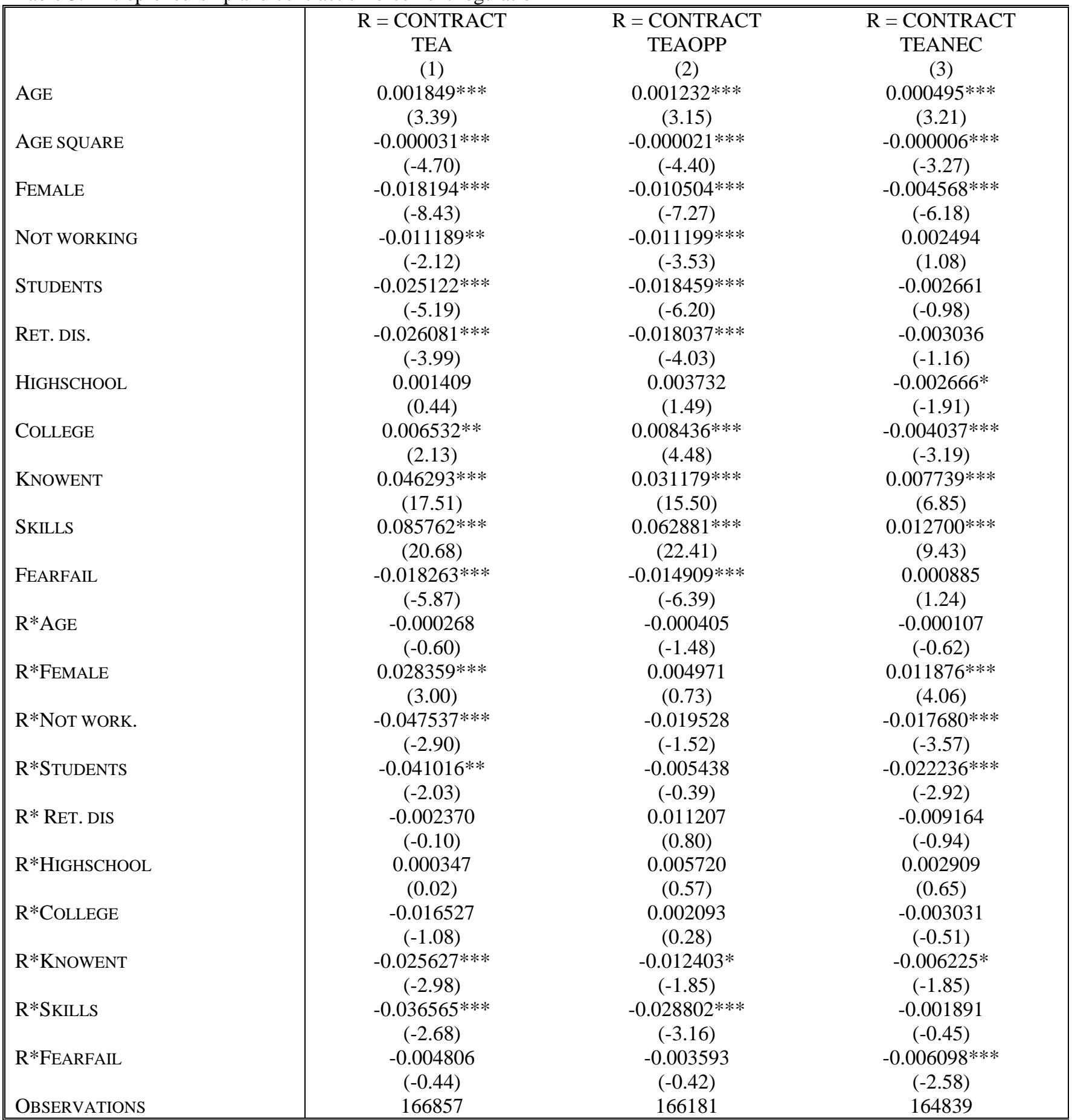

Notes: Probit regressions including country fixed effects and time dummies. Standard errors are clustered at the country level. Marginal effects (not coefficients) and t-stat. are shown in the tables. ${ }^{* * *},{ }^{* *}, *$ coefficients statistically significant at $1 \%, 5 \%$, and $10 \%$ level, respectively. TEA $=1$ if individuals are starting a new business or are owners and managers of a young firm, 0 otherwise; TEAOPP = 1 if individuals are starting a new business or are owners and managers of a young firm to take advantage of a business opportunity, 0 otherwise; TEANEC $=1$ if individuals are starting a new business or are owners and managers of a young firm because they could find no better economic work, 0 otherwise; CONTRACT measures the efficiency of the justice system in resolving commercial disputes; CONTRACT $=$ (procedures + quality of bureaucracy)/2. See Appendix I and Appendix II for the exact definition of the variables. 
Table 4: Entrepreneurship and regulation of labor

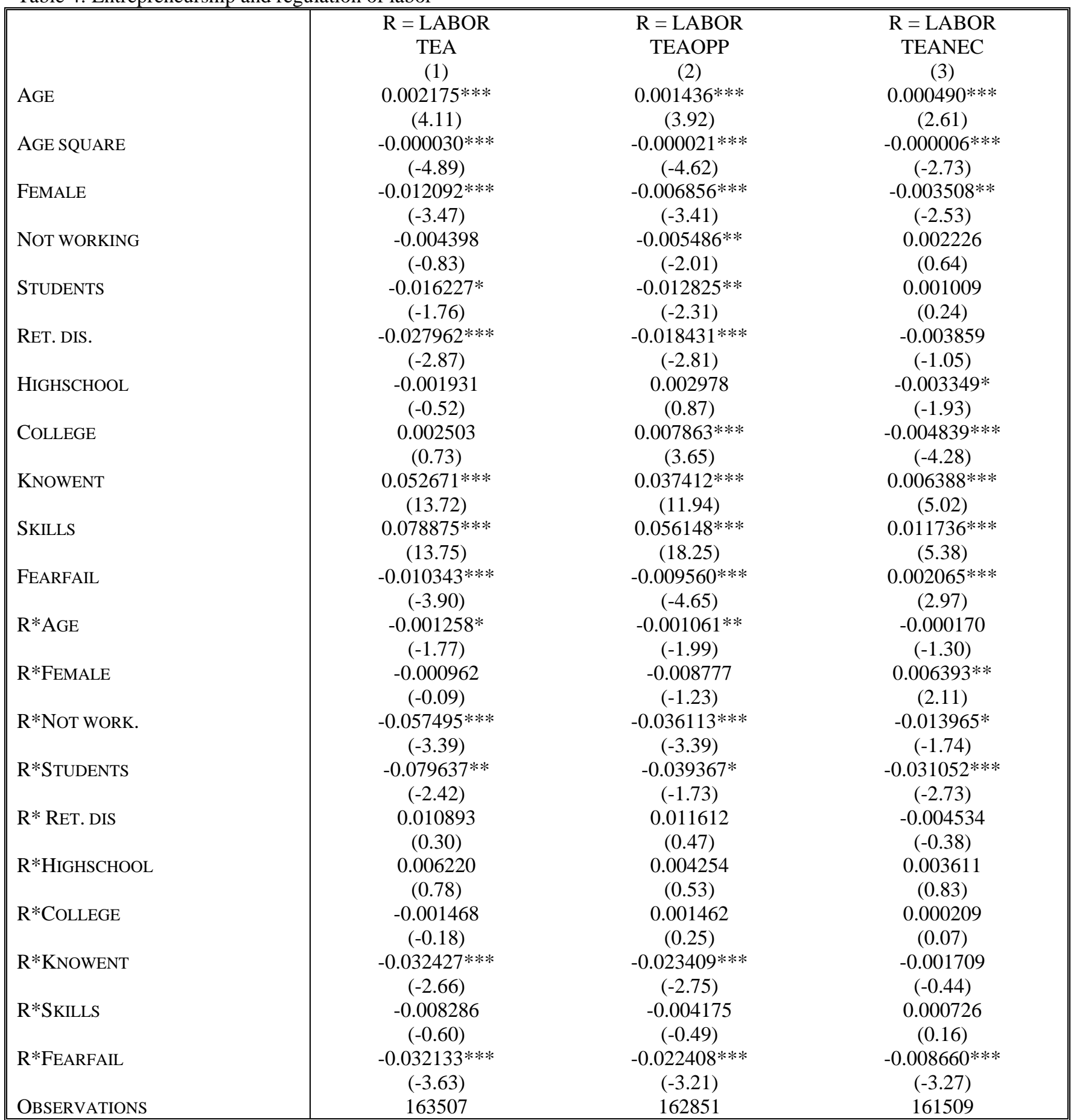

Notes: Probit regressions including country fixed effects and time dummies. Standard errors are clustered at the country level. Marginal effects (not coefficients) and t-stat. are shown in the tables. ${ }^{* * *}$, **, $*$ coefficients statistically significant at $1 \%, 5 \%$, and $10 \%$ level, respectively. TEA $=1$ if individuals are starting a new business or are owners and managers of a young firm, 0 otherwise; TEAOPP $=1$ if individuals are starting a new business or are owners and managers of a young firm to take advantage of a business opportunity, 0 otherwise; TEANEC $=1$ if individuals are starting a new business or are owners and managers of a young firm because they could find no better economic work, 0 otherwise; LABOR measures the difficulty for entrepreneurs of adjusting the labor force. LABOR = (hiring index + firing index + firing costs + rigidity of labor contracts + union density)/5. See Appendix I and Appendix II for the exact definition of the variables. 
Table 5: Entrepreneurship, regulation and income

\begin{tabular}{|c|c|c|c|c|c|c|c|c|c|}
\hline & $\begin{array}{c}\mathrm{R}= \\
\text { ENTRY } \\
\text { TEA }\end{array}$ & $\begin{array}{c}\mathrm{R}= \\
\text { ENTRY } \\
\text { TEAOPP }\end{array}$ & $\begin{array}{c}\mathrm{R}= \\
\text { ENTRY } \\
\text { TEANEC }\end{array}$ & $\begin{array}{c}\mathrm{R}= \\
\text { CONTRACT } \\
\text { TEA }\end{array}$ & $\begin{array}{c}\mathrm{R}= \\
\text { CONTRACT } \\
\text { TEAOPP }\end{array}$ & $\begin{array}{c}\mathrm{R}= \\
\text { CONTRACT } \\
\text { TEANEC }\end{array}$ & $\begin{array}{c}\mathrm{R}= \\
\text { LABOR } \\
\text { TEA }\end{array}$ & $\begin{array}{c}\mathrm{R}= \\
\text { LABOR } \\
\text { TEAOPP }\end{array}$ & $\begin{array}{c}\mathrm{R}= \\
\text { LABOR } \\
\text { TEANEC }\end{array}$ \\
\hline AGE & $\begin{array}{l}0.0017^{* * *} \\
(2.64)\end{array}$ & $\begin{array}{l}0.0012^{* * *} \\
(2.61)\end{array}$ & $\begin{array}{l}0.0004^{* *} \\
(2.43)\end{array}$ & $\begin{array}{l}0.0014 * * \\
(2.17)\end{array}$ & $\begin{array}{l}0.0010^{* *} \\
(2.20)\end{array}$ & $\begin{array}{l}0.0004^{* *} \\
(2.40)\end{array}$ & $\begin{array}{l}0.0017^{* * * *} \\
(2.99)\end{array}$ & $\begin{array}{l}0.0012^{* * *} \\
(2.86)\end{array}$ & $\begin{array}{l}0.0004^{*} \\
(1.68)\end{array}$ \\
\hline AGE SQUARE & $-0.0000 * *$ & $-0.0000 * *$ & $-0.0000 * *$ & $-0.0000 * * *$ & $-0.0000 * * *$ & $-0.0000 * *$ & $-0.0000 * *$ & $-0.0000 * *$ & $-0.0000 *$ \\
\hline FEMALE & $\begin{array}{l}-0.019 * * * \\
(-5.07)\end{array}$ & $\begin{array}{l}-0.009 * * * \\
(-3.95)\end{array}$ & $\begin{array}{l}-0.005^{* * *} \\
(-4.16)\end{array}$ & $\begin{array}{l}-0.0175^{* * * *} \\
(-8.25)\end{array}$ & $\begin{array}{l}-0.0098 * * * \\
(-6.96)\end{array}$ & $\begin{array}{l}-0.0044 * * * \\
(-5.05)\end{array}$ & $\begin{array}{l}-0.013 * * * \\
(-4.23)\end{array}$ & $\begin{array}{l}-0.007 * * * \\
(-4.07)\end{array}$ & $\begin{array}{l}-0.004 * * * \\
(-2.96)\end{array}$ \\
\hline NOT WORKING & $\begin{array}{l}0.0010 \\
(0.16)\end{array}$ & $\begin{array}{l}-0.0048 \\
(-1.11)\end{array}$ & $\begin{array}{l}0.0048 \\
(1.31)\end{array}$ & $\begin{array}{l}-0.0085 \\
(-1.54)\end{array}$ & $\begin{array}{l}-0.0088 * * * \\
(-2.95)\end{array}$ & $\begin{array}{l}0.0019 \\
(0.61)\end{array}$ & $\begin{array}{l}-0.0052 \\
(-0.92)\end{array}$ & $\begin{array}{l}-0.0050 * * \\
(-2.26)\end{array}$ & $\begin{array}{l}0.0010 \\
(0.22)\end{array}$ \\
\hline STUDENTS & $\begin{array}{l}-0.0140^{*} \\
(-1.66)\end{array}$ & $\begin{array}{l}-0.0115^{*} \\
(-1.73)\end{array}$ & $\begin{array}{l}0.0009 \\
(0.21)\end{array}$ & $\begin{array}{l}-0.0247 * * * \\
(-3.96)\end{array}$ & $\begin{array}{l}-0.0178 * * * \\
(-3.90)\end{array}$ & $\begin{array}{l}-0.0036 \\
(-1.22)\end{array}$ & $\begin{array}{l}-0.0119 \\
(-1.24)\end{array}$ & $\begin{array}{l}-0.0090 \\
(-1.26)\end{array}$ & $\begin{array}{l}0.0006 \\
(0.14)\end{array}$ \\
\hline RET. DIS & $\begin{array}{l}-0.032 * * * \\
(-2.79)\end{array}$ & $\begin{array}{l}-0.022^{* * *} \\
(-2.91)\end{array}$ & $\begin{array}{l}-0.0031 \\
(-0.76)\end{array}$ & $\begin{array}{l}-0.0269 * * * \\
(-3.01)\end{array}$ & $\begin{array}{l}-0.0186 * * * \\
(-3.13)\end{array}$ & $\begin{array}{l}-0.0023 \\
(-0.74)\end{array}$ & $\begin{array}{l}-0.0308^{* *} \\
(-2.48)\end{array}$ & $\begin{array}{l}-0.0198^{* *} \\
(-2.50)\end{array}$ & $\begin{array}{l}-0.0045 \\
(-1.03)\end{array}$ \\
\hline HIGHSCHOOL & $\begin{array}{l}-0.0032 \\
(-0.61)\end{array}$ & $\begin{array}{l}0.0017 \\
(0.44)\end{array}$ & $\begin{array}{l}-0.0042 * * \\
(-2.50)\end{array}$ & $\begin{array}{l}-0.0011 \\
(-0.30)\end{array}$ & $\begin{array}{l}0.0019 \\
(0.67)\end{array}$ & $\begin{array}{l}-0.0032^{* *} \\
(-2.04)\end{array}$ & $\begin{array}{l}-0.0002 \\
(-0.06)\end{array}$ & $\begin{array}{l}0.0036 \\
(0.99)\end{array}$ & $\begin{array}{l}-0.0028 \\
(-1.64)\end{array}$ \\
\hline College & $\begin{array}{l}0.0047 \\
(0.88)\end{array}$ & $\begin{array}{l}0.0074^{* *} \\
(2.00)\end{array}$ & $\begin{array}{l}-0.0041 * \\
(-1.91)\end{array}$ & $\begin{array}{l}0.0026 \\
(0.64)\end{array}$ & $\begin{array}{l}0.0049 * \\
(1.68)\end{array}$ & $\begin{array}{l}-0.0037^{* *} \\
(-2.31)\end{array}$ & $\begin{array}{l}0.0042 \\
(1.11)\end{array}$ & $\begin{array}{l}0.0078^{* *} \\
(2.53)\end{array}$ & $\begin{array}{l}-0.0033^{* *} \\
(-2.79)\end{array}$ \\
\hline KNOWENT & $\begin{array}{l}0.0554^{* * * *} \\
(14.78)\end{array}$ & $\begin{array}{l}0.0374^{* * * *} \\
(12.48)\end{array}$ & $\begin{array}{l}0.0081^{* * * *} \\
(5.29)\end{array}$ & $\begin{array}{l}0.0480^{* * * *} \\
(17.40)\end{array}$ & $\begin{array}{l}0.0307^{* * *} \\
(15.41)\end{array}$ & $\begin{array}{l}0.0091^{* * * *} \\
(6.61)\end{array}$ & $\begin{array}{l}0.0529 * * * \\
(17.26)\end{array}$ & $\begin{array}{l}0.0357^{* * * *} \\
(14.82)\end{array}$ & $\begin{array}{l}0.0074 * * * \\
(5.46)\end{array}$ \\
\hline SKILLS & $\begin{array}{l}0.0975 * * * \\
(20.18)\end{array}$ & $\begin{array}{l}0.0667 * * * \\
(20.66)\end{array}$ & $\begin{array}{l}0.0168^{* * *} \\
(8.66)\end{array}$ & $\begin{array}{l}0.0906^{* * *} \\
(23.52)\end{array}$ & $\begin{array}{l}0.0649 * * * \\
(26.50)\end{array}$ & $\begin{array}{l}0.0143^{* * *} \\
(9.87)\end{array}$ & $\begin{array}{l}0.0839 * * * \\
(14.98)\end{array}$ & $\begin{array}{l}0.0588^{* * *} \\
(22.55)\end{array}$ & $\begin{array}{l}0.0132 * * * \\
(5.91)\end{array}$ \\
\hline FEARFAIL & $\begin{array}{l}-0.018^{* * *} \\
(-3.87)\end{array}$ & $\begin{array}{l}-0.014^{* * *} \\
(-4.11)\end{array}$ & $\begin{array}{l}0.0005 \\
(0.53)\end{array}$ & $\begin{array}{l}-0.0194 * * * \\
(-4.91)\end{array}$ & $\begin{array}{l}-0.0153^{* * * *} \\
(-5.28)\end{array}$ & $\begin{array}{l}0.0003 \\
(0.34)\end{array}$ & $\begin{array}{l}-0.011 * * * \\
(-3.51)\end{array}$ & $\begin{array}{l}-0.001 * * * \\
(-4.28)\end{array}$ & $\begin{array}{l}0.0022^{* * *} \\
(2.86)\end{array}$ \\
\hline $\mathrm{R}^{*} \mathrm{AGE}$ & $\begin{array}{l}-0.0011 \\
(-1.51)\end{array}$ & $\begin{array}{l}-0.0011^{*} \\
(-1.88)\end{array}$ & $\begin{array}{l}-0.0002 \\
(-0.81)\end{array}$ & $\begin{array}{l}-0.0003 \\
(-0.54)\end{array}$ & $\begin{array}{l}-0.0004 \\
(-1.16)\end{array}$ & $\begin{array}{l}-0.0002 \\
(-0.79)\end{array}$ & $\begin{array}{l}-0.0015^{* *} \\
(-2.13)\end{array}$ & $\begin{array}{l}-0.0013^{* *} \\
(-2.44)\end{array}$ & $\begin{array}{l}-0.0001 \\
(-1.08)\end{array}$ \\
\hline R*FEMALE & $\begin{array}{l}0.0243 \\
(1.62)\end{array}$ & $\begin{array}{l}-0.0007 \\
(-0.07)\end{array}$ & $\begin{array}{l}0.0130 * * * \\
(2.92)\end{array}$ & $\begin{array}{l}0.0275^{* * *} \\
(2.72)\end{array}$ & $\begin{array}{l}0.0020 \\
(0.27)\end{array}$ & $\begin{array}{l}0.0124^{* * *} \\
(3.77)\end{array}$ & $\begin{array}{l}0.0054 \\
(0.54)\end{array}$ & $\begin{array}{l}-0.0060 \\
(-0.85)\end{array}$ & $\begin{array}{l}0.0093^{* * *} \\
(3.17)\end{array}$ \\
\hline $\mathrm{R}^{*}$ NOT WORK. & $\begin{array}{l}-0.077 * * * \\
(-4.29)\end{array}$ & $\begin{array}{l}-0.0331 * \\
(-1.93)\end{array}$ & $\begin{array}{l}-0.023^{* * *} \\
(-3.38)\end{array}$ & $\begin{array}{l}-0.0564 * * * \\
(-3.57)\end{array}$ & $\begin{array}{l}-0.0225 \\
(-1.64)\end{array}$ & $\begin{array}{l}-0.0187 * * * \\
(-2.93)\end{array}$ & $\begin{array}{l}-0.055^{* * *} \\
(-2.89)\end{array}$ & $\begin{array}{l}-0.032 * * * \\
(-2.81)\end{array}$ & $\begin{array}{l}-0.0138 \\
(-1.30)\end{array}$ \\
\hline $\mathrm{R}$ *STUDENTS & $\begin{array}{l}-0.0937 * * \\
(-2.57)\end{array}$ & $\begin{array}{l}-0.0406 \\
(-1.28)\end{array}$ & $\begin{array}{l}-0.039 * * * \\
(-3.40)\end{array}$ & $\begin{array}{l}-0.0448 * * \\
(-1.96)\end{array}$ & $\begin{array}{l}-0.0031 \\
(-0.16)\end{array}$ & $\begin{array}{l}-0.0245^{* *} \\
(-2.51)\end{array}$ & $\begin{array}{l}-0.103^{* * * *} \\
(-2.83)\end{array}$ & $\begin{array}{l}-0.0526^{*} \\
(-1.86)\end{array}$ & $\begin{array}{l}-0.039 * * * \\
(-3.31)\end{array}$ \\
\hline $\mathrm{R}^{*}$ RET. DIS & $\begin{array}{l}0.0370 \\
(0.72)\end{array}$ & $\begin{array}{l}0.0506 \\
(1.47)\end{array}$ & $\begin{array}{l}-0.0090 \\
(-0.56)\end{array}$ & $\begin{array}{l}-0.0033 \\
(-0.08)\end{array}$ & $\begin{array}{l}0.0204 \\
(0.76)\end{array}$ & $\begin{array}{l}-0.0155 \\
(-1.16)\end{array}$ & $\begin{array}{l}0.0261 \\
(0.54)\end{array}$ & $\begin{array}{l}0.0245 \\
(0.78)\end{array}$ & $\begin{array}{l}-0.0023 \\
(-0.15)\end{array}$ \\
\hline R*HIGHSCHOOL & $\begin{array}{l}0.0105 \\
(0.64)\end{array}$ & $\begin{array}{l}0.0066 \\
(0.64)\end{array}$ & $\begin{array}{l}0.0074 \\
(1.62)\end{array}$ & $\begin{array}{l}0.0086 \\
(0.49)\end{array}$ & $\begin{array}{l}0.0095 \\
(0.89)\end{array}$ & $\begin{array}{l}0.0056 \\
(1.22)\end{array}$ & $\begin{array}{l}-0.0008 \\
(-0.10)\end{array}$ & $\begin{array}{l}-0.0000 \\
(-0.00)\end{array}$ & $\begin{array}{l}0.0029 \\
(0.61)\end{array}$ \\
\hline $\mathrm{R}^{*}$ COLLEGE & $\begin{array}{l}-0.0190 \\
(-1.07)\end{array}$ & $\begin{array}{l}-0.0069 \\
(-0.68)\end{array}$ & $\begin{array}{l}-0.0014 \\
(-0.17)\end{array}$ & $\begin{array}{l}-0.0124 \\
(-0.70)\end{array}$ & $\begin{array}{l}0.0032 \\
(0.33)\end{array}$ & $\begin{array}{l}-0.0035 \\
(-0.51)\end{array}$ & $\begin{array}{l}-0.0156 \\
(-1.63)\end{array}$ & $\begin{array}{l}-0.0073 \\
(-0.95)\end{array}$ & $\begin{array}{l}-0.0042 \\
(-1.00)\end{array}$ \\
\hline $\mathrm{R}$ *KNOWENT & $\begin{array}{l}-0.039 * * * \\
(-3.28)\end{array}$ & $\begin{array}{l}-0.027 * * * \\
(-2.94)\end{array}$ & $\begin{array}{l}-0.0040 \\
(-0.88)\end{array}$ & $\begin{array}{l}-0.0270 * * * \\
(-2.73)\end{array}$ & $\begin{array}{l}-0.0115 \\
(-1.44)\end{array}$ & $\begin{array}{l}-0.0077^{*} \\
(-1.92)\end{array}$ & $\begin{array}{l}-0.0304^{* *} \\
(-2.55)\end{array}$ & $\begin{array}{l}-0.021 * * * \\
(-2.79)\end{array}$ & $\begin{array}{l}-0.0021 \\
(-0.46)\end{array}$ \\
\hline $\mathrm{R}^{*}$ SKILLS & $\begin{array}{l}-0.047 * * * \\
(-3.12)\end{array}$ & $\begin{array}{l}-0.0261^{* *} \\
(-2.53)\end{array}$ & $\begin{array}{l}-0.0079 \\
(-1.49)\end{array}$ & $\begin{array}{l}-0.0409 * * * \\
(-2.73)\end{array}$ & $\begin{array}{l}-0.0305^{* * *} \\
(-3.25)\end{array}$ & $\begin{array}{l}-0.0032 \\
(-0.71)\end{array}$ & $\begin{array}{l}-0.0124 \\
(-0.91)\end{array}$ & $\begin{array}{l}-0.0071 \\
(-0.94)\end{array}$ & $\begin{array}{l}0.0000 \\
(0.01)\end{array}$ \\
\hline $\mathrm{R}^{*}$ FEARFAIL & $\begin{array}{l}-0.0100 \\
(-0.72)\end{array}$ & $\begin{array}{l}-0.0072 \\
(-0.65)\end{array}$ & $\begin{array}{l}-0.0053^{*} \\
(-1.83)\end{array}$ & $\begin{array}{l}-0.0042 \\
(-0.32)\end{array}$ & $\begin{array}{l}-0.0030 \\
(-0.31)\end{array}$ & $\begin{array}{l}-0.0054^{* *} \\
(-2.12)\end{array}$ & $\begin{array}{l}-0.035^{* * *} \\
(-3.54)\end{array}$ & $\begin{array}{l}-0.023^{* * *} \\
(-2.95)\end{array}$ & $\begin{array}{l}-0.011^{* * *} \\
(-4.24)\end{array}$ \\
\hline Lowest Income & $\begin{array}{l}0.0004 \\
(0.07)\end{array}$ & $\begin{array}{l}0.0011 \\
(0.27)\end{array}$ & $\begin{array}{l}0.0025 \\
(1.38)\end{array}$ & $\begin{array}{l}-0.0012 \\
(-0.42)\end{array}$ & $\begin{array}{l}-0.0024 \\
(-0.96)\end{array}$ & $\begin{array}{l}0.0033^{* * * *} \\
(3.34)\end{array}$ & $\begin{array}{l}0.0004 \\
(0.08)\end{array}$ & $\begin{array}{l}-0.0041 \\
(-1.33)\end{array}$ & $\begin{array}{l}0.0050^{* * *} \\
(2.80)\end{array}$ \\
\hline Upper Income & $\begin{array}{l}-0.0091^{*} \\
(-1.66)\end{array}$ & $\begin{array}{l}-0.0044 \\
(-1.16)\end{array}$ & $\begin{array}{l}-0.0036^{* *} \\
(-2.30)\end{array}$ & $\begin{array}{l}0.0005 \\
(0.10)\end{array}$ & $\begin{array}{l}0.0026 \\
(0.76)\end{array}$ & $\begin{array}{l}-0.0030 * * * \\
(-2.63)\end{array}$ & $\begin{array}{l}-0.0076^{*} \\
(-1.76)\end{array}$ & $\begin{array}{l}-0.0030 \\
(-1.10)\end{array}$ & $\begin{array}{l}-0.0035^{* *} \\
(-2.40)\end{array}$ \\
\hline $\mathrm{R}^{*}$ Low Income & $\begin{array}{l}0.0072 \\
(0.30)\end{array}$ & $\begin{array}{l}-0.0101 \\
(-0.79)\end{array}$ & $\begin{array}{l}0.0009 \\
(0.14)\end{array}$ & $\begin{array}{l}0.0150 \\
(0.80)\end{array}$ & $\begin{array}{l}0.0025 \\
(0.18)\end{array}$ & $\begin{array}{l}-0.0014 \\
(-0.31)\end{array}$ & $\begin{array}{l}0.0116 \\
(1.19)\end{array}$ & $\begin{array}{l}0.0096 \\
(1.28)\end{array}$ & $\begin{array}{l}-0.0049 \\
(-1.53)\end{array}$ \\
\hline $\mathrm{R} * \mathrm{Upp}$ Income & $\begin{array}{l}0.0549 * * * \\
(3.03)\end{array}$ & $\begin{array}{l}0.0411^{* * * *} \\
(3.07)\end{array}$ & $\begin{array}{l}0.0043 \\
(1.07)\end{array}$ & $\begin{array}{l}0.0246 \\
(1.20)\end{array}$ & $\begin{array}{l}0.0205 \\
(1.47)\end{array}$ & $\begin{array}{l}0.0027 \\
(0.62)\end{array}$ & $\begin{array}{l}0.0459^{* * * *} \\
(3.45)\end{array}$ & $\begin{array}{l}0.0322^{* * *} \\
(3.41)\end{array}$ & $\begin{array}{l}0.0044 \\
(0.93)\end{array}$ \\
\hline OBSERVATIONS & 122276 & 121769 & 120698 & 122276 & 121769 & 120698 & 119140 & 118653 & 117582 \\
\hline
\end{tabular}

Notes: Probit regressions including country fixed effects and time dummies. Standard errors are clustered at the country level. Marginal effects (not coefficients) and t-stat. are shown in the tables. ***, **, * coefficients statistically significant at $1 \%, 5 \%$, and $10 \%$ level, respectively. TEA $=1$ if individuals are starting a new business or are owners and managers of a young firm, 0 otherwise; TEAOPP = 1 if individuals are starting a new business or are owners and managers of a young firm to take advantage of a business opportunity, 0 otherwise; TEANEC $=1$ if individuals are starting a new business or are owners and managers of a young firm because they could find no better economic work, 0 otherwise; ENTRY measures the barriers and costs entrepreneurs face when they decide to create a new business; ENTRY $=$ (procedures + time + cost + regulation (IEF))/4. CONTRACT measures the efficiency of the justice system in resolving commercial disputes; CONTRACT $=$ (procedures + quality of bureaucracy $) / 2$. LABOR measures the difficulty for entrepreneurs of adjusting the labor force. $\mathrm{LABOR}=$ (hiring index + firing index + firing costs + rigidity of labor contracts + union density) $/ 5$. See Appendix I and Appendix II for the exact definition of the variables. 
Table 6: Entrepreneurship and regulation: evidence from the Flash Eurobarometer

\begin{tabular}{|c|c|c|c|c|c|c|c|c|c|}
\hline & $\begin{array}{c}\mathrm{R}=\text { ENTRY } \\
\text { TEA }\end{array}$ & $\begin{array}{c}\mathrm{R}=\text { ENTRY } \\
\text { TEAOPP }\end{array}$ & $\begin{array}{c}\mathrm{R}=\text { ENTRY } \\
\text { TEANEC }\end{array}$ & $\begin{array}{c}\mathrm{R}= \\
\text { CONTRACT } \\
\text { TEA }\end{array}$ & $\begin{array}{c}\mathrm{R}= \\
\text { CONTRACT } \\
\text { TEAOPP }\end{array}$ & $\begin{array}{c}\mathrm{R}= \\
\text { CONTRACT } \\
\text { TEANEC }\end{array}$ & $\begin{array}{c}\mathrm{R}=\underset{\mathrm{LABOR}}{\mathrm{LAA}} \\
\text { TEA }\end{array}$ & $\begin{array}{c}\mathrm{R}=\mathrm{LABOR} \\
\text { TEAOPP }\end{array}$ & $\begin{array}{c}\mathrm{R}=\mathrm{LABOR} \\
\text { TEANEC }\end{array}$ \\
\hline AGE & $\begin{array}{l}-0.000089 \\
(-0.07)\end{array}$ & $\begin{array}{l}0.007330^{* * * *} \\
(4.00)\end{array}$ & $\begin{array}{l}0.004457 * * * \\
(3.60)\end{array}$ & $\begin{array}{l}0.001273 \\
(1.17)\end{array}$ & $\begin{array}{l}0.008547^{* * * *} \\
(4.80)\end{array}$ & $\begin{array}{l}0.005262 * * * \\
(4.54)\end{array}$ & $\begin{array}{l}0.001083 \\
(0.88)\end{array}$ & $\begin{array}{l}0.007938 * * * \\
(5.37)\end{array}$ & $\begin{array}{l}0.004972 * * * \\
(3.86)\end{array}$ \\
\hline AGE SQUARE & $\begin{array}{l}-0.000034 * * \\
(-2.41)\end{array}$ & $\begin{array}{l}-0.00008^{* * *} \\
(-4.52)\end{array}$ & $\begin{array}{l}-0.00004 * * * \\
(-3.02)\end{array}$ & $\begin{array}{l}-0.000037 * * \\
(-2.56)\end{array}$ & $\begin{array}{l}-0.00008 * * * \\
(-4.63)\end{array}$ & $\begin{array}{l}-0.00004 * * * \\
(-3.18)\end{array}$ & $\begin{array}{l}-0.000038 * * \\
(-2.51)\end{array}$ & $\begin{array}{l}-0.00009 * * * \\
(-5.22)\end{array}$ & $\begin{array}{l}-0.00005^{* * * *} \\
(-3.13)\end{array}$ \\
\hline FEMALE & $\begin{array}{l}-0.04005^{* * *} \\
(-4.86)\end{array}$ & $\begin{array}{l}-0.09299 * * * \\
(-7.17)\end{array}$ & $\begin{array}{l}-0.04050^{* * *} \\
(-4.81)\end{array}$ & $\begin{array}{l}-0.04053^{* * * *} \\
(-7.27)\end{array}$ & $\begin{array}{l}-0.07119 * * * \\
(-6.68)\end{array}$ & $\begin{array}{l}-0.03757 * * * \\
(-4.98)\end{array}$ & $\begin{array}{l}-0.04594 * * * \\
(-5.77)\end{array}$ & $\begin{array}{l}-0.10174 * * * \\
(-6.99)\end{array}$ & $\begin{array}{l}-0.03296 * * * \\
(-3.76)\end{array}$ \\
\hline NOT WORKING & $\begin{array}{l}0.009715 \\
(0.34)\end{array}$ & $\begin{array}{l}-0.017990 \\
(-0.67)\end{array}$ & $\begin{array}{l}0.001678 \\
(0.07)\end{array}$ & $\begin{array}{l}0.012157 \\
(0.99)\end{array}$ & $\begin{array}{l}-0.013903 \\
(-0.96)\end{array}$ & $\begin{array}{l}-0.004663 \\
(-0.42)\end{array}$ & $\begin{array}{l}0.006065 \\
(0.29)\end{array}$ & $\begin{array}{l}-0.015741 \\
(-0.66)\end{array}$ & $\begin{array}{l}0.002709 \\
(0.11)\end{array}$ \\
\hline STUDENTS & $\begin{array}{l}0.026004 \\
(0.79)\end{array}$ & $\begin{array}{l}0.019790 \\
(0.50)\end{array}$ & $\begin{array}{l}0.032528 \\
(0.82)\end{array}$ & $\begin{array}{l}-0.036349 * * \\
(-2.03)\end{array}$ & $\begin{array}{l}-0.055110 * * \\
(-2.57)\end{array}$ & $\begin{array}{l}0.018021 \\
(0.90)\end{array}$ & $\begin{array}{l}0.033572 \\
(1.31)\end{array}$ & $\begin{array}{l}0.005737 \\
(0.16)\end{array}$ & $\begin{array}{l}0.015880 \\
(0.40)\end{array}$ \\
\hline RET. DIS & $\begin{array}{l}-0.041197 * * \\
(-2.03)\end{array}$ & $\begin{array}{l}-0.008437 \\
(-0.35)\end{array}$ & $\begin{array}{l}-0.002658 \\
(-0.26)\end{array}$ & $\begin{array}{l}-0.05203^{* * * *} \\
(-3.95)\end{array}$ & $\begin{array}{l}-0.028123^{* *} \\
(-2.27)\end{array}$ & $\begin{array}{l}-0.02301^{* * *} \\
(-3.45)\end{array}$ & $\begin{array}{l}-0.05081^{* * * *} \\
(-3.39)\end{array}$ & $\begin{array}{l}-0.0471^{* * *} \\
(-2.60)\end{array}$ & $\begin{array}{l}-0.02144 * * * \\
(-2.83)\end{array}$ \\
\hline HIGHSCHOOL & $\begin{array}{l}0.020390 \\
(1.02)\end{array}$ & $\begin{array}{l}-0.019015 \\
(-1.40)\end{array}$ & $\begin{array}{l}-0.006018 \\
(-0.52)\end{array}$ & $\begin{array}{l}0.024281 * * \\
(2.00)\end{array}$ & $\begin{array}{l}0.010078 \\
(0.82)\end{array}$ & $\begin{array}{l}-0.006696 \\
(-1.12)\end{array}$ & $\begin{array}{l}0.033919 \\
(1.35)\end{array}$ & $\begin{array}{l}0.016906 \\
(1.03)\end{array}$ & $\begin{array}{l}0.026462 \\
(1.53)\end{array}$ \\
\hline College & $\begin{array}{l}0.041322^{* *} \\
(2.09)\end{array}$ & $\begin{array}{l}-0.019708 \\
(-1.01)\end{array}$ & $\begin{array}{l}0.024702 * \\
(1.74)\end{array}$ & $\begin{array}{l}0.047612 * * * \\
(3.72)\end{array}$ & $\begin{array}{l}0.019213 \\
(1.50)\end{array}$ & $\begin{array}{l}0.000663 \\
(0.08)\end{array}$ & $\begin{array}{l}0.053978 * * * \\
(2.59)\end{array}$ & $\begin{array}{l}0.033264 * \\
(1.72)\end{array}$ & $\begin{array}{l}0.041228 * \\
(1.75)\end{array}$ \\
\hline KNOWENT & $\begin{array}{l}0.030756^{* * * *} \\
(2.91)\end{array}$ & $\begin{array}{l}0.108556^{* * * *} \\
(7.76)\end{array}$ & $\begin{array}{l}0.014613 \\
(1.46)\end{array}$ & $\begin{array}{l}0.027173^{* * * *} \\
(4.30)\end{array}$ & $\begin{array}{l}0.076525^{* * * *} \\
(6.91)\end{array}$ & $\begin{array}{l}0.031865^{* * * *} \\
(5.54)\end{array}$ & $\begin{array}{l}0.029109^{* * * *} \\
(3.24)\end{array}$ & $\begin{array}{l}0.080674 * * * \\
(5.33)\end{array}$ & $\begin{array}{l}0.001511 \\
(0.15)\end{array}$ \\
\hline FEARFAIL & $\begin{array}{l}-0.03047 * * * \\
(-3.42)\end{array}$ & $\begin{array}{l}-0.05226 * * * \\
(-3.31)\end{array}$ & $\begin{array}{l}-0.009229 \\
(-0.90)\end{array}$ & $\begin{array}{l}-0.02473 * * * \\
(-3.36)\end{array}$ & $\begin{array}{l}-0.04031^{* * *} \\
(-4.72)\end{array}$ & $\begin{array}{l}-0.004764 \\
(-0.61)\end{array}$ & $\begin{array}{l}-0.03324 * * * \\
(-4.70)\end{array}$ & $\begin{array}{l}-0.03661^{* * *} \\
(-3.16)\end{array}$ & $\begin{array}{l}-0.017823 * * \\
(-2.33)\end{array}$ \\
\hline $\mathrm{R}^{*} \mathrm{AGE}$ & $\begin{array}{l}0.003495 * \\
(1.69)\end{array}$ & $\begin{array}{l}0.000166 \\
(0.08)\end{array}$ & $\begin{array}{l}0.001899 \\
(1.52)\end{array}$ & $\begin{array}{l}-0.000337 \\
(-0.31)\end{array}$ & $\begin{array}{l}-0.003259 * \\
(-1.68)\end{array}$ & $\begin{array}{l}-0.000526 \\
(-0.55)\end{array}$ & $\begin{array}{l}0.000616 \\
(0.50)\end{array}$ & $\begin{array}{l}0.000830 \\
(0.65)\end{array}$ & $\begin{array}{l}0.000932 \\
(1.12)\end{array}$ \\
\hline $\mathrm{R} *$ FEMALE & $\begin{array}{l}-0.002580 \\
(-0.08)\end{array}$ & $\begin{array}{l}0.049213 \\
(0.97)\end{array}$ & $\begin{array}{l}0.043265^{*} \\
(1.86)\end{array}$ & $\begin{array}{l}-0.000641 \\
(-0.02)\end{array}$ & $\begin{array}{l}-0.025704 \\
(-0.63)\end{array}$ & $\begin{array}{l}0.037085^{* *} \\
(2.03)\end{array}$ & $\begin{array}{l}0.010541 \\
(0.50)\end{array}$ & $\begin{array}{l}0.051975 \\
(1.51)\end{array}$ & $\begin{array}{l}0.015446 \\
(0.79)\end{array}$ \\
\hline R*NOT WORK. & $\begin{array}{l}-0.089421 \\
(-1.05)\end{array}$ & $\begin{array}{l}-0.047220 \\
(-0.57)\end{array}$ & $\begin{array}{l}-0.066691 \\
(-1.04)\end{array}$ & $\begin{array}{l}-0.1059 * * * \\
(-2.80)\end{array}$ & $\begin{array}{l}-0.066689 \\
(-1.38)\end{array}$ & $\begin{array}{l}-0.047161^{*} \\
(-1.76)\end{array}$ & $\begin{array}{l}-0.070444 \\
(-1.33)\end{array}$ & $\begin{array}{l}-0.052964 \\
(-0.88)\end{array}$ & $\begin{array}{l}-0.056499 \\
(-1.05)\end{array}$ \\
\hline R*STUDENTS & $\begin{array}{l}-0.24559 * * * \\
(-2.98)\end{array}$ & $\begin{array}{l}-0.29041^{* * *} \\
(-2.74)\end{array}$ & $\begin{array}{l}-0.211062 * * \\
(-2.25)\end{array}$ & $\begin{array}{l}-0.031780 \\
(-0.53)\end{array}$ & $\begin{array}{l}-0.021334 \\
(-0.27)\end{array}$ & $\begin{array}{l}-0.19071^{* * * *} \\
(-3.40)\end{array}$ & $\begin{array}{l}-0.21378^{* * * *} \\
(-4.32)\end{array}$ & $\begin{array}{l}-0.190310 * * \\
(-2.40)\end{array}$ & $\begin{array}{l}-0.126665 \\
(-1.31)\end{array}$ \\
\hline $\mathrm{R}^{*} \mathrm{RET}$. DIS & $\begin{array}{l}-0.015639 \\
(-0.20)\end{array}$ & $\begin{array}{l}-0.108904 \\
(-1.08)\end{array}$ & $\begin{array}{l}-0.11587 * * * \\
(-4.13)\end{array}$ & $\begin{array}{l}0.059530 \\
(0.95)\end{array}$ & $\begin{array}{l}-0.029452 \\
(-0.46)\end{array}$ & $\begin{array}{l}-0.038155 \\
(-1.32)\end{array}$ & $\begin{array}{l}0.037028 \\
(0.79)\end{array}$ & $\begin{array}{l}0.030218 \\
(0.51)\end{array}$ & $\begin{array}{l}-0.037098 \\
(-1.57)\end{array}$ \\
\hline R*HIGHSCHOOL & $\begin{array}{l}-0.028136 \\
(-0.52)\end{array}$ & $\begin{array}{l}0.102267 * * \\
(2.41)\end{array}$ & $\begin{array}{l}0.000387 \\
(0.01)\end{array}$ & $\begin{array}{l}-0.049622 \\
(-1.38)\end{array}$ & $\begin{array}{l}0.007268 \\
(0.18)\end{array}$ & $\begin{array}{l}-0.003207 \\
(-0.19)\end{array}$ & $\begin{array}{l}-0.057882 \\
(-1.06)\end{array}$ & $\begin{array}{l}-0.008891 \\
(-0.22)\end{array}$ & $\begin{array}{l}-0.082123^{* *} \\
(-2.18)\end{array}$ \\
\hline $\mathrm{R}^{*}$ COLlEGE & $\begin{array}{l}-0.019051 \\
(-0.35)\end{array}$ & $\begin{array}{l}0.158038 * * * \\
(2.76)\end{array}$ & $\begin{array}{l}-0.089565 * * \\
(-2.27)\end{array}$ & $\begin{array}{l}-0.044914 \\
(-1.22)\end{array}$ & $\begin{array}{l}0.029434 \\
(0.75)\end{array}$ & $\begin{array}{l}-0.023256 \\
(-0.84)\end{array}$ & $\begin{array}{l}-0.041490 \\
(-0.97)\end{array}$ & $\begin{array}{l}-0.007041 \\
(-0.17)\end{array}$ & $\begin{array}{l}-0.105944 * * \\
(-2.35)\end{array}$ \\
\hline $\mathrm{R}^{*}$ KNOWENT & $\begin{array}{l}-0.008938 \\
(-0.35)\end{array}$ & $\begin{array}{l}-0.15843^{* * * *} \\
(-4.29)\end{array}$ & $\begin{array}{l}0.014256 \\
(0.61)\end{array}$ & $\begin{array}{l}0.003508 \\
(0.17)\end{array}$ & $\begin{array}{l}-0.085465^{* *} \\
(-2.29)\end{array}$ & $\begin{array}{l}-0.03482^{* * * *} \\
(-2.64)\end{array}$ & $\begin{array}{l}-0.004975 \\
(-0.25)\end{array}$ & $\begin{array}{l}-0.067928 * \\
(-1.88)\end{array}$ & $\begin{array}{l}0.043378^{* *} \\
(1.97)\end{array}$ \\
\hline $\mathrm{R} *$ FEARFAIL & $\begin{array}{l}0.040639 \\
(1.26)\end{array}$ & $\begin{array}{l}0.073837 \\
(1.44)\end{array}$ & $\begin{array}{l}-0.006364 \\
(-0.21)\end{array}$ & $\begin{array}{l}0.024288 \\
(0.87)\end{array}$ & $\begin{array}{l}0.038357 \\
(1.26)\end{array}$ & $\begin{array}{l}-0.022928 \\
(-1.04)\end{array}$ & $\begin{array}{l}0.039216^{* *} \\
(2.22)\end{array}$ & $\begin{array}{l}0.015569 \\
(0.47)\end{array}$ & $\begin{array}{l}0.019748 \\
(0.92)\end{array}$ \\
\hline $\mathrm{R}$ & $\begin{array}{l}-0.069532 \\
(-0.52)\end{array}$ & $\begin{array}{l}-0.169835 \\
(-0.82)\end{array}$ & $\begin{array}{l}-0.075221 \\
(-0.68)\end{array}$ & $\begin{array}{l}-0.026147 \\
(-0.46)\end{array}$ & $\begin{array}{l}0.021280 \\
(0.18)\end{array}$ & $\begin{array}{l}0.135216^{* *} \\
(2.08)\end{array}$ & $\begin{array}{l}0.007363 \\
(0.08)\end{array}$ & $\begin{array}{l}-0.038774 \\
(-0.22)\end{array}$ & $\begin{array}{l}0.015832 \\
(0.21)\end{array}$ \\
\hline OBSERVATIONS & 26355 & 26355 & 26355 & 26355 & 26355 & 26355 & 25349 & 25349 & 25349 \\
\hline
\end{tabular}

Notes: Probit regressions including country fixed effects and time dummies. Standard errors are clustered at the country level. Marginal effects (not coefficients) and t-stat. are shown in the tables. ***, **, * coefficients statistically significant at $1 \%, 5 \%$, and $10 \%$ level, respectively. TEA $=1$ if individuals are starting a new business or are owners and managers of a young firm, 0 otherwise; TEAOPP $=1$ if individuals are starting a new business or are owners and managers of a young firm to take advantage of a business opportunity, 0 otherwise; TEANEC $=1$ if individuals are starting a new business or are owners and managers of a young firm because they could find no better economic work, 0 otherwise; ENTRY measures the barriers and costs entrepreneurs face when they decide to create a new business; ENTRY $=$ (procedures + time + cost + regulation (IEF))/4. CONTRACT measures the efficiency of the justice system in resolving commercial disputes; CONTRACT $=$ (procedures + quality of bureaucracy) $/ 2$. LABOR measures the difficulty for entrepreneurs of adjusting the labor force. $\mathrm{LABOR}=$ (hiring index + firing index + firing costs + rigidity of labor contracts + union density) $/ 5$. See Appendix I and Appendix III for the exact definition of the variables. 
Table 7: Entrepreneurship and regulation - Instrumental variables estimation (weighted data)

\begin{tabular}{|c|c|c|c|c|c|c|c|c|c|}
\hline & $\begin{array}{c}\mathrm{R}= \\
\text { ENTRY } \\
\text { TEA }\end{array}$ & $\begin{array}{c}\mathrm{R}= \\
\text { ENTRY } \\
\text { TEAOPP }\end{array}$ & $\begin{array}{c}\mathrm{R}= \\
\text { ENTRY } \\
\text { TEANEC }\end{array}$ & $\begin{array}{c}\mathrm{R}= \\
\text { CONTRACT } \\
\text { TEA }\end{array}$ & $\begin{array}{c}\mathrm{R}= \\
\text { CONTRACT } \\
\text { TEAOPP }\end{array}$ & $\begin{array}{c}\mathrm{R}= \\
\text { CONTRACT } \\
\text { TEANEC }\end{array}$ & $\begin{array}{c}\mathrm{R}= \\
\text { LABOR } \\
\text { TEA }\end{array}$ & $\begin{array}{c}\mathrm{R}= \\
\text { LABOR } \\
\text { TEAOPP }\end{array}$ & $\begin{array}{c}\mathrm{R}= \\
\text { LABOR } \\
\text { TEANEC }\end{array}$ \\
\hline AGE & $\begin{array}{l}0.0017^{*} \\
(1.96)\end{array}$ & $\begin{array}{l}0.0013^{* *} \\
(2.13)\end{array}$ & $\begin{array}{l}0.0003 \\
(0.88)\end{array}$ & $\begin{array}{l}0.0016^{*} \\
(1.86)\end{array}$ & $\begin{array}{l}0.0011^{*} \\
(1.86)\end{array}$ & $\begin{array}{l}0.0004 \\
(1.15)\end{array}$ & $\begin{array}{l}0.0019 * * \\
(2.39)\end{array}$ & $\begin{array}{l}0.0015^{* *} \\
(2.70)\end{array}$ & $\begin{array}{l}0.0003 \\
(0.87)\end{array}$ \\
\hline AGE SQUARE & $\begin{array}{l}-0.0000 * * \\
(-3.09)\end{array}$ & $\begin{array}{l}-0.0000 * * \\
(-3.08)\end{array}$ & $\begin{array}{l}-0.0000^{*} \\
(-1.86)\end{array}$ & $\begin{array}{l}-0.0000 * * * \\
(-3.03)\end{array}$ & $\begin{array}{l}-0.0000^{* * *} \\
(-2.95)\end{array}$ & $\begin{array}{l}-0.0000^{*} \\
(-1.88)\end{array}$ & $\begin{array}{l}-0.0000 * * \\
(-3.42)\end{array}$ & $\begin{array}{l}-0.0000 * * \\
(-3.40)\end{array}$ & $\begin{array}{l}-0.0000^{*} \\
(-1.96)\end{array}$ \\
\hline FEMALE & $\begin{array}{l}-0.033^{* * *} \\
(-5.50)\end{array}$ & $\begin{array}{l}-0.021 * * * \\
(-4.51)\end{array}$ & $\begin{array}{l}-0.010 * * * \\
(-3.50)\end{array}$ & $\begin{array}{l}-0.0272^{* * *} \\
(-6.08)\end{array}$ & $\begin{array}{l}-0.0172 * * * \\
(-4.84)\end{array}$ & $\begin{array}{l}-0.0086 * * * \\
(-3.20)\end{array}$ & $\begin{array}{l}-0.029 * * * \\
(-5.70)\end{array}$ & $\begin{array}{l}-0.018 * * * \\
(-4.20)\end{array}$ & $\begin{array}{l}-0.009 * * * \\
(-4.54)\end{array}$ \\
\hline NOT WORKING & $\begin{array}{l}-0.0070 \\
(-0.58)\end{array}$ & $\begin{array}{l}-0.0108 \\
(-1.45)\end{array}$ & $\begin{array}{l}0.0039 \\
(0.54)\end{array}$ & $\begin{array}{l}-0.0102 \\
(-1.07)\end{array}$ & $\begin{array}{l}-0.0103 \\
(-1.62)\end{array}$ & $\begin{array}{l}0.0004 \\
(0.08)\end{array}$ & $\begin{array}{l}-0.0102 \\
(-1.05)\end{array}$ & $\begin{array}{l}-0.0133 * * \\
(-2.07)\end{array}$ & $\begin{array}{l}0.0030 \\
(0.48)\end{array}$ \\
\hline STUDENTS & $\begin{array}{l}-0.028 * * * \\
(-2.94)\end{array}$ & $\begin{array}{l}-0.026 * * * \\
(-3.39)\end{array}$ & $\begin{array}{l}0.0003 \\
(0.04)\end{array}$ & $\begin{array}{l}-0.0345^{* * * *} \\
(-4.09)\end{array}$ & $\begin{array}{l}-0.0313^{* * * *} \\
(-4.66)\end{array}$ & $\begin{array}{l}-0.0004 \\
(-0.08)\end{array}$ & $\begin{array}{l}-0.0238^{*} \\
(-1.85)\end{array}$ & $\begin{array}{l}-0.0202^{*} \\
(-1.87)\end{array}$ & $\begin{array}{l}-0.0015 \\
(-0.14)\end{array}$ \\
\hline RET. DIS & $\begin{array}{l}-0.037 * * * \\
(-2.87)\end{array}$ & $\begin{array}{l}-0.036 * * * \\
(-3.16)\end{array}$ & $\begin{array}{l}0.0028 \\
(0.62)\end{array}$ & $\begin{array}{l}-0.0348^{* * * *} \\
(-3.11)\end{array}$ & $\begin{array}{l}-0.0324^{* * *} \\
(-3.12)\end{array}$ & $\begin{array}{l}0.0009 \\
(0.27)\end{array}$ & $\begin{array}{l}-0.044 * * * \\
(-3.12)\end{array}$ & $\begin{array}{l}-0.040 * * * \\
(-3.28)\end{array}$ & $\begin{array}{l}0.0001 \\
(0.03)\end{array}$ \\
\hline HIGHSCHOOL & $\begin{array}{l}0.0136 \\
(1.34)\end{array}$ & $\begin{array}{l}0.0150 * * \\
(2.12)\end{array}$ & $\begin{array}{l}-0.0013 \\
(-0.21)\end{array}$ & $\begin{array}{l}0.0115 \\
(1.59)\end{array}$ & $\begin{array}{l}0.0115 * * \\
(2.25)\end{array}$ & $\begin{array}{l}0.0008 \\
(0.17)\end{array}$ & $\begin{array}{l}0.0043 \\
(0.54)\end{array}$ & $\begin{array}{l}0.0095^{*} \\
(1.73)\end{array}$ & $\begin{array}{l}-0.0055 \\
(-0.91)\end{array}$ \\
\hline COLlEGE & $\begin{array}{l}0.0190^{*} \\
(1.97)\end{array}$ & $\begin{array}{l}0.0197 * * * \\
(3.44)\end{array}$ & $\begin{array}{l}-0.0010 \\
(-0.15)\end{array}$ & $\begin{array}{l}0.0164 * * \\
(2.34)\end{array}$ & $\begin{array}{l}0.0170 * * * \\
(4.00)\end{array}$ & $\begin{array}{l}-0.0001 \\
(-0.03)\end{array}$ & $\begin{array}{l}0.0077 \\
(0.97)\end{array}$ & $\begin{array}{l}0.0147 * * * \\
(4.07)\end{array}$ & $\begin{array}{l}-0.0081 \\
(-1.38)\end{array}$ \\
\hline KNOWENT & $\begin{array}{l}0.0884^{* * * *} \\
(7.45)\end{array}$ & $\begin{array}{l}0.0809^{* * *} \\
(8.01)\end{array}$ & $\begin{array}{l}0.0028 \\
(0.76)\end{array}$ & $\begin{array}{l}0.0743^{* * *} \\
(7.14)\end{array}$ & $\begin{array}{l}0.0663^{* * * *} \\
(7.35)\end{array}$ & $\begin{array}{l}0.0043 \\
(1.45)\end{array}$ & $\begin{array}{l}0.0950 * * * \\
(13.75)\end{array}$ & $\begin{array}{l}0.0838 * * * \\
(13.87)\end{array}$ & $\begin{array}{l}0.0061^{*} \\
(1.94)\end{array}$ \\
\hline SKILLS & $\begin{array}{l}0.1045^{* * * *} \\
(5.57)\end{array}$ & $\begin{array}{l}0.0879 * * * \\
(6.06)\end{array}$ & $\begin{array}{l}0.0123^{*} \\
(2.02)\end{array}$ & $\begin{array}{l}0.1003 * * * \\
(6.93)\end{array}$ & $\begin{array}{l}0.0840^{* * * *} \\
(7.44)\end{array}$ & $\begin{array}{l}0.0120 * * * \\
(3.12)\end{array}$ & $\begin{array}{l}0.1050 * * * \\
(5.36)\end{array}$ & $\begin{array}{l}0.0823^{* * * *} \\
(5.72)\end{array}$ & $\begin{array}{l}0.0178 * * \\
(2.48)\end{array}$ \\
\hline FEARFAIL & $\begin{array}{l}-0.022 * * * \\
(-4.21)\end{array}$ & $\begin{array}{l}-0.024 * * * \\
(-5.76)\end{array}$ & $\begin{array}{l}0.0026 \\
(1.27)\end{array}$ & $\begin{array}{l}-0.0242^{* * * *} \\
(-5.69)\end{array}$ & $\begin{array}{l}-0.0244 * * * \\
(-7.07)\end{array}$ & $\begin{array}{l}0.0012 \\
(0.83)\end{array}$ & $\begin{array}{l}-0.022 * * * \\
(-5.26)\end{array}$ & $\begin{array}{l}-0.024 * * * \\
(-6.12)\end{array}$ & $\begin{array}{l}0.0017 \\
(0.90)\end{array}$ \\
\hline $\mathrm{R}^{*} \mathrm{AGE}$ & $\begin{array}{l}-0.0006 \\
(-0.50)\end{array}$ & $\begin{array}{l}-0.0009 \\
(-0.97)\end{array}$ & $\begin{array}{l}0.0004 \\
(0.81)\end{array}$ & $\begin{array}{l}-0.0004 \\
(-0.39)\end{array}$ & $\begin{array}{l}-0.0007 \\
(-0.80)\end{array}$ & $\begin{array}{l}0.0002 \\
(0.58)\end{array}$ & $\begin{array}{l}-0.0009 \\
(-0.79)\end{array}$ & $\begin{array}{l}-0.0010 \\
(-1.18)\end{array}$ & $\begin{array}{l}0.0004 \\
(0.81)\end{array}$ \\
\hline $\mathrm{R}^{*}$ FEMALE & $\begin{array}{l}0.0606 * * \\
(2.27)\end{array}$ & $\begin{array}{l}0.0237 \\
(1.24)\end{array}$ & $\begin{array}{l}0.0312^{* *} \\
(2.28)\end{array}$ & $\begin{array}{l}0.0578 * * \\
(2.05)\end{array}$ & $\begin{array}{l}0.0172 \\
(0.83)\end{array}$ & $\begin{array}{l}0.0357 * * \\
(2.12)\end{array}$ & $\begin{array}{l}0.0381 * \\
(2.01)\end{array}$ & $\begin{array}{l}0.0126 \\
(0.82)\end{array}$ & $\begin{array}{l}0.0218^{* * * *} \\
(2.73)\end{array}$ \\
\hline R*NOT WORK. & $\begin{array}{l}-0.0654 \\
(-1.50)\end{array}$ & $\begin{array}{l}-0.0261 \\
(-0.95)\end{array}$ & $\begin{array}{l}-0.0327 \\
(-1.38)\end{array}$ & $\begin{array}{l}-0.0781 * \\
(-1.83)\end{array}$ & $\begin{array}{l}-0.0397 \\
(-1.34)\end{array}$ & $\begin{array}{l}-0.0308 \\
(-1.35)\end{array}$ & $\begin{array}{l}-0.0433 \\
(-1.24)\end{array}$ & $\begin{array}{l}-0.0133 \\
(-0.61)\end{array}$ & $\begin{array}{l}-0.0242 \\
(-1.31)\end{array}$ \\
\hline R*STUDENTS & $\begin{array}{l}-0.0718 \\
(-1.56)\end{array}$ & $\begin{array}{l}-0.0339 \\
(-1.09)\end{array}$ & $\begin{array}{l}-0.0374 \\
(-1.28)\end{array}$ & $\begin{array}{l}-0.0682 \\
(-1.35)\end{array}$ & $\begin{array}{l}-0.0242 \\
(-0.68)\end{array}$ & $\begin{array}{l}-0.0456 \\
(-1.67)\end{array}$ & $\begin{array}{l}-0.0773 \\
(-1.60)\end{array}$ & $\begin{array}{l}-0.0485 \\
(-1.41)\end{array}$ & $\begin{array}{l}-0.0280 \\
(-0.81)\end{array}$ \\
\hline $\mathrm{R}^{*}$ RET. DIS & $\begin{array}{l}0.0350 \\
(0.78)\end{array}$ & $\begin{array}{l}0.0648 * \\
(1.72)\end{array}$ & $\begin{array}{l}-0.0327 \\
(-1.66)\end{array}$ & $\begin{array}{l}0.0355 \\
(0.74)\end{array}$ & $\begin{array}{l}0.0703^{*} \\
(1.74)\end{array}$ & $\begin{array}{l}-0.0368 * \\
(-1.71)\end{array}$ & $\begin{array}{l}0.0545 \\
(1.32)\end{array}$ & $\begin{array}{l}0.0717^{* *} \\
(2.16)\end{array}$ & $\begin{array}{l}-0.0211 \\
(-1.23)\end{array}$ \\
\hline R*HIGHSCHOOL & $\begin{array}{l}-0.0449 \\
(-1.51)\end{array}$ & $\begin{array}{l}-0.0350 \\
(-1.59)\end{array}$ & $\begin{array}{l}-0.0078 \\
(-0.42)\end{array}$ & $\begin{array}{l}-0.0529 * \\
(-1.86)\end{array}$ & $\begin{array}{l}-0.0327 \\
(-1.46)\end{array}$ & $\begin{array}{l}-0.0200 \\
(-1.08)\end{array}$ & $\begin{array}{l}-0.0151 \\
(-0.76)\end{array}$ & $\begin{array}{l}-0.0171 \\
(-1.17)\end{array}$ & $\begin{array}{l}0.0051 \\
(0.35)\end{array}$ \\
\hline $\mathrm{R}^{*}$ COLLEGE & $\begin{array}{l}-0.0607^{*} \\
(-1.94)\end{array}$ & $\begin{array}{l}-0.0297 \\
(-1.47)\end{array}$ & $\begin{array}{l}-0.0293 \\
(-1.18)\end{array}$ & $\begin{array}{l}-0.0712 * * \\
(-2.50)\end{array}$ & $\begin{array}{l}-0.0269 \\
(-1.21)\end{array}$ & $\begin{array}{l}-0.0451^{*} \\
(-1.88)\end{array}$ & $\begin{array}{l}-0.0205 \\
(-0.91)\end{array}$ & $\begin{array}{l}-0.0134 \\
(-1.01)\end{array}$ & $\begin{array}{l}-0.0030 \\
(-0.18)\end{array}$ \\
\hline $\mathrm{R}^{*} \mathrm{KNOWENT}$ & $\begin{array}{l}-0.110 * * * \\
(-2.99)\end{array}$ & $\begin{array}{l}-0.124 * * * \\
(-4.12)\end{array}$ & $\begin{array}{l}0.0208 \\
(1.58)\end{array}$ & $\begin{array}{l}-0.0886^{*} \\
(-1.85)\end{array}$ & $\begin{array}{l}-0.1070 * * \\
(-2.69)\end{array}$ & $\begin{array}{l}0.0228 \\
(1.61)\end{array}$ & $\begin{array}{l}-0.116 * * * \\
(-5.39)\end{array}$ & $\begin{array}{l}-0.116^{* * *} \\
(-6.56)\end{array}$ & $\begin{array}{l}0.0080 \\
(0.84)\end{array}$ \\
\hline $\mathrm{R} *$ SKILLS & $\begin{array}{l}-0.0577 \\
(-1.14)\end{array}$ & $\begin{array}{l}-0.0706^{*} \\
(-1.81)\end{array}$ & $\begin{array}{l}0.0147 \\
(0.70)\end{array}$ & $\begin{array}{l}-0.0625 \\
(-1.15)\end{array}$ & $\begin{array}{l}-0.0835^{* *} \\
(-2.04)\end{array}$ & $\begin{array}{l}0.0230 \\
(1.18)\end{array}$ & $\begin{array}{l}-0.0504 \\
(-1.06)\end{array}$ & $\begin{array}{l}-0.0435 \\
(-1.23)\end{array}$ & $\begin{array}{l}-0.0039 \\
(-0.20)\end{array}$ \\
\hline R*FEARFAIL & $\begin{array}{l}-0.0221 \\
(-1.07)\end{array}$ & $\begin{array}{l}-0.0047 \\
(-0.32)\end{array}$ & $\begin{array}{l}-0.0154 * \\
(-1.74)\end{array}$ & $\begin{array}{l}-0.0186 \\
(-0.76)\end{array}$ & $\begin{array}{l}-0.0014 \\
(-0.08)\end{array}$ & $\begin{array}{l}-0.0155^{*} \\
(-1.73)\end{array}$ & $\begin{array}{l}-0.0193 \\
(-1.35)\end{array}$ & $\begin{array}{l}-0.0065 \\
(-0.59)\end{array}$ & $\begin{array}{l}-0.0108 * \\
(-1.69)\end{array}$ \\
\hline OBSERVATIONS & 166857 & 166181 & 166181 & 166857 & 166181 & 166181 & 163507 & 162851 & 162851 \\
\hline
\end{tabular}

Notes: IV regressions including country fixed effects and time dummies. Standard errors are clustered at the country level. Instruments for the regulatory variable $\mathrm{R}$ are dummy variables measuring English (common law), French (civil law), Socialist, German and Scandinavian legal origin. Coefficients and t-stat. are shown in the tables. ***, **,* coefficients statistically significant at 1\%, 5\%, and 10\% level, respectively. TEA $=1$ if individuals are starting a new business or are owners and managers of a young firm, 0 otherwise; TEAOPP = 1 if individuals are starting a new business or are owners and managers of a young firm to take advantage of a business opportunity, 0 otherwise; TEANEC $=1$ if individuals are starting a new business or are owners and managers of a young firm because they could find no better economic work, 0 otherwise. ENTRY measures the barriers and costs entrepreneurs face when they decide to create a new business; ENTRY $=($ procedures + time + cost + regulation $($ IEF) $) / 4$. CONTRACT measures the efficiency of the justice system in resolving commercial disputes; CONTRACT $=$ (procedures + quality of bureaucracy) $/ 2$. LABOR measures the difficulty for entrepreneurs of adjusting the labor force. LABOR = (hiring index + firing index + firing costs + rigidity of labor contracts + union density)/5. See Appendix I and Appendix II for the exact definitions of the variables. 
Figure 1: Entrepreneurship and regulation across the world

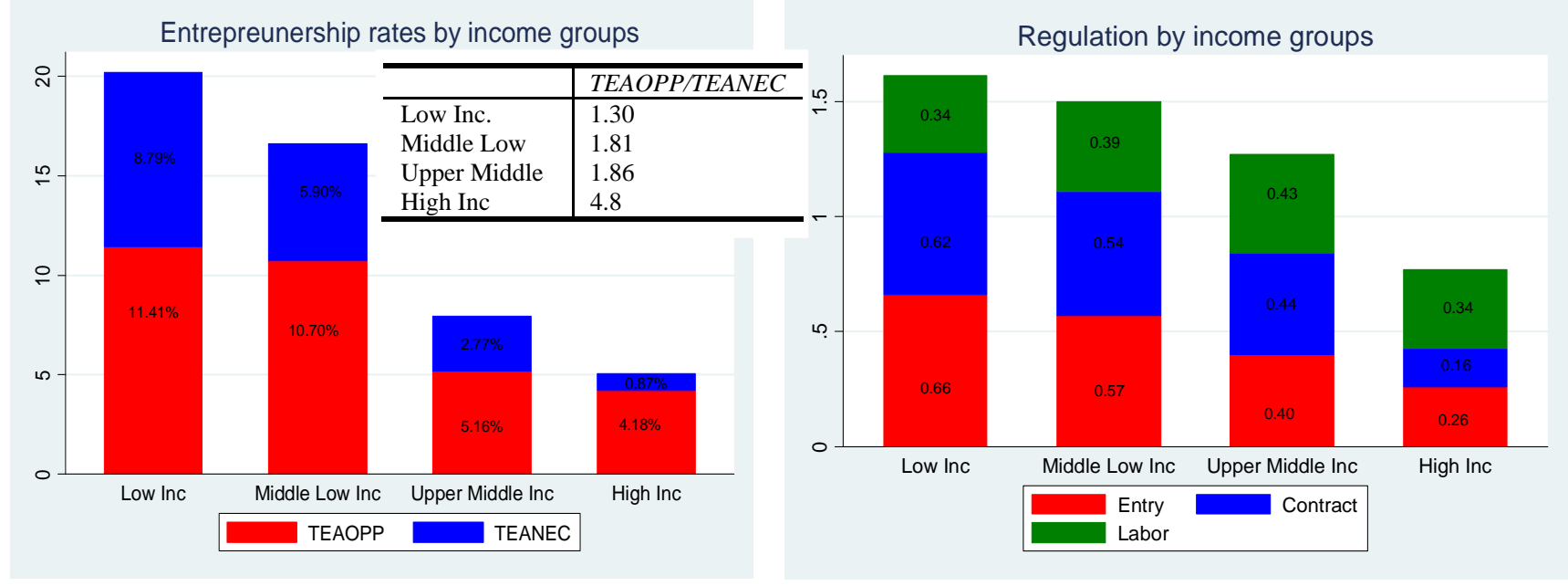

Entrepreunership rates by geographic regions
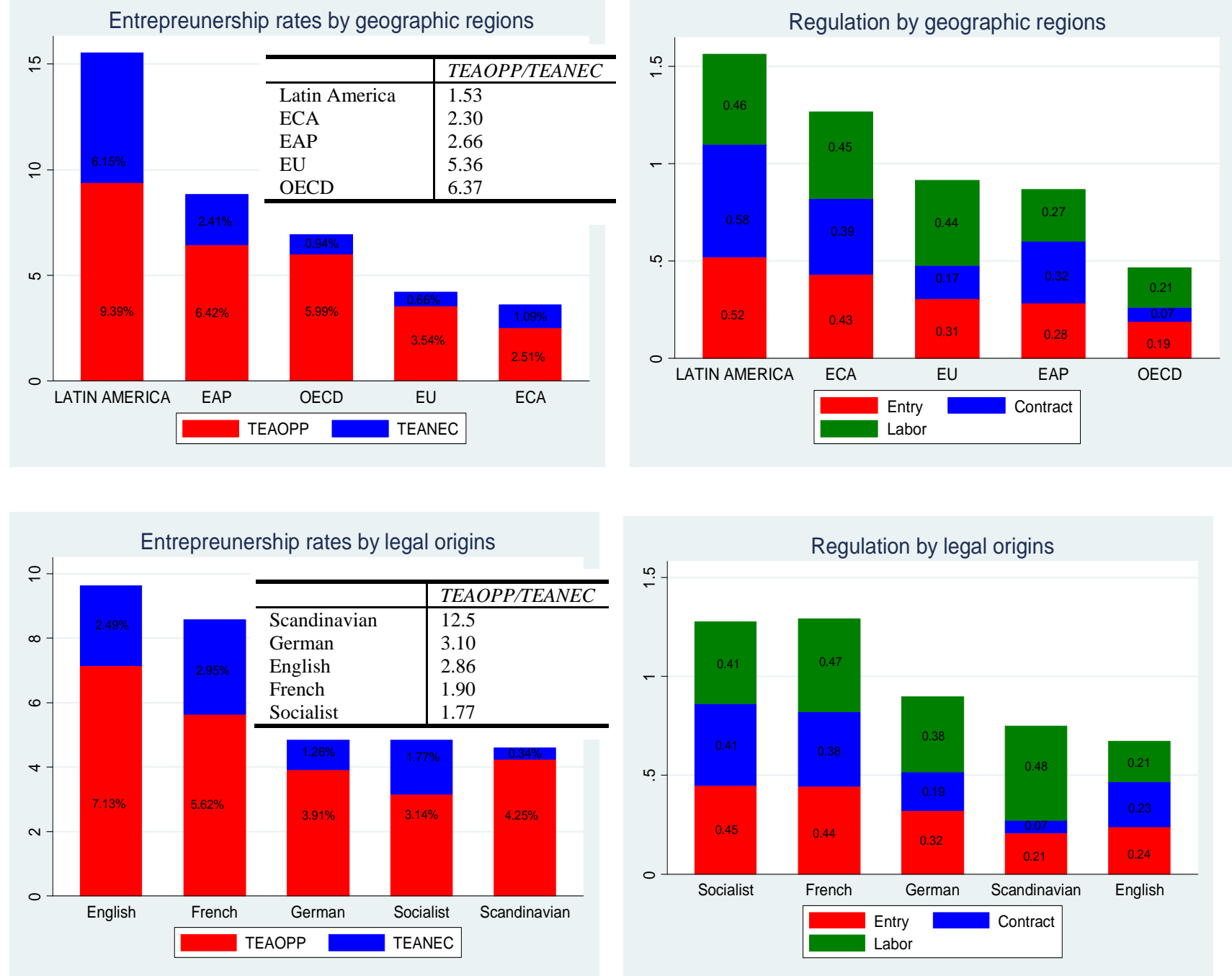

Notes: See Appendix I. 
Figure 2: Opportunity entrepreneurs, necessity entrepreneurs and their business activities

\section{Sector of activity}
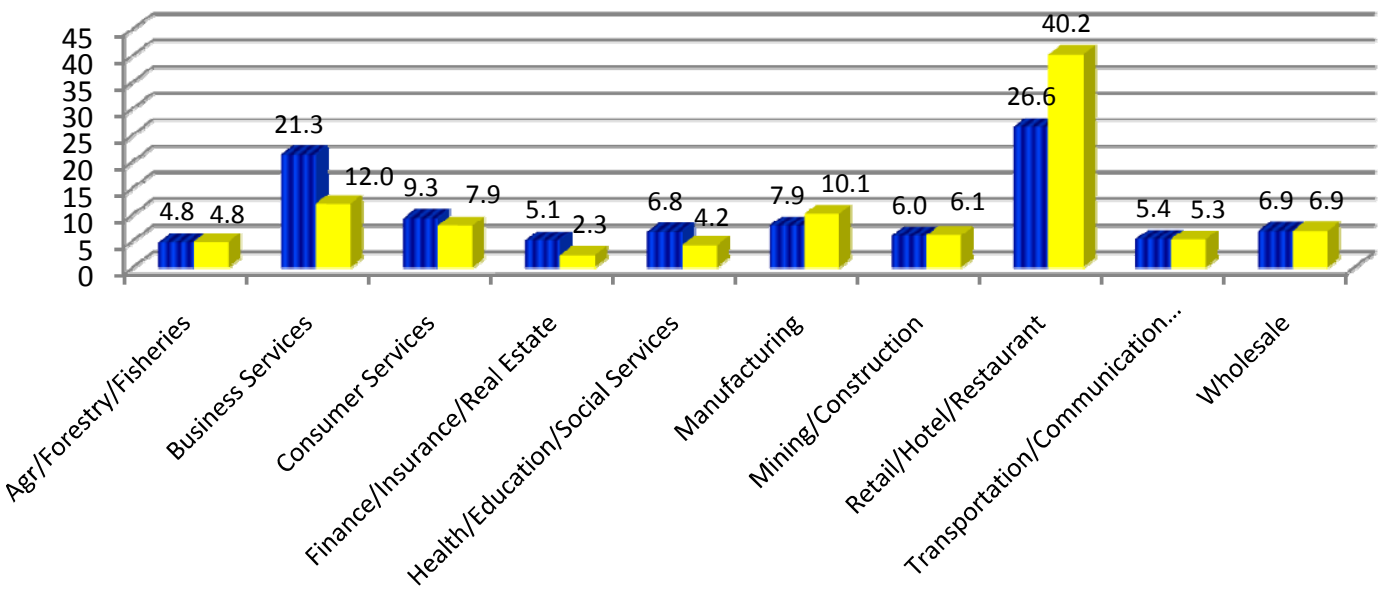

II TEAOPP (\%) TEANEC (\%)

\section{Product Innovation}

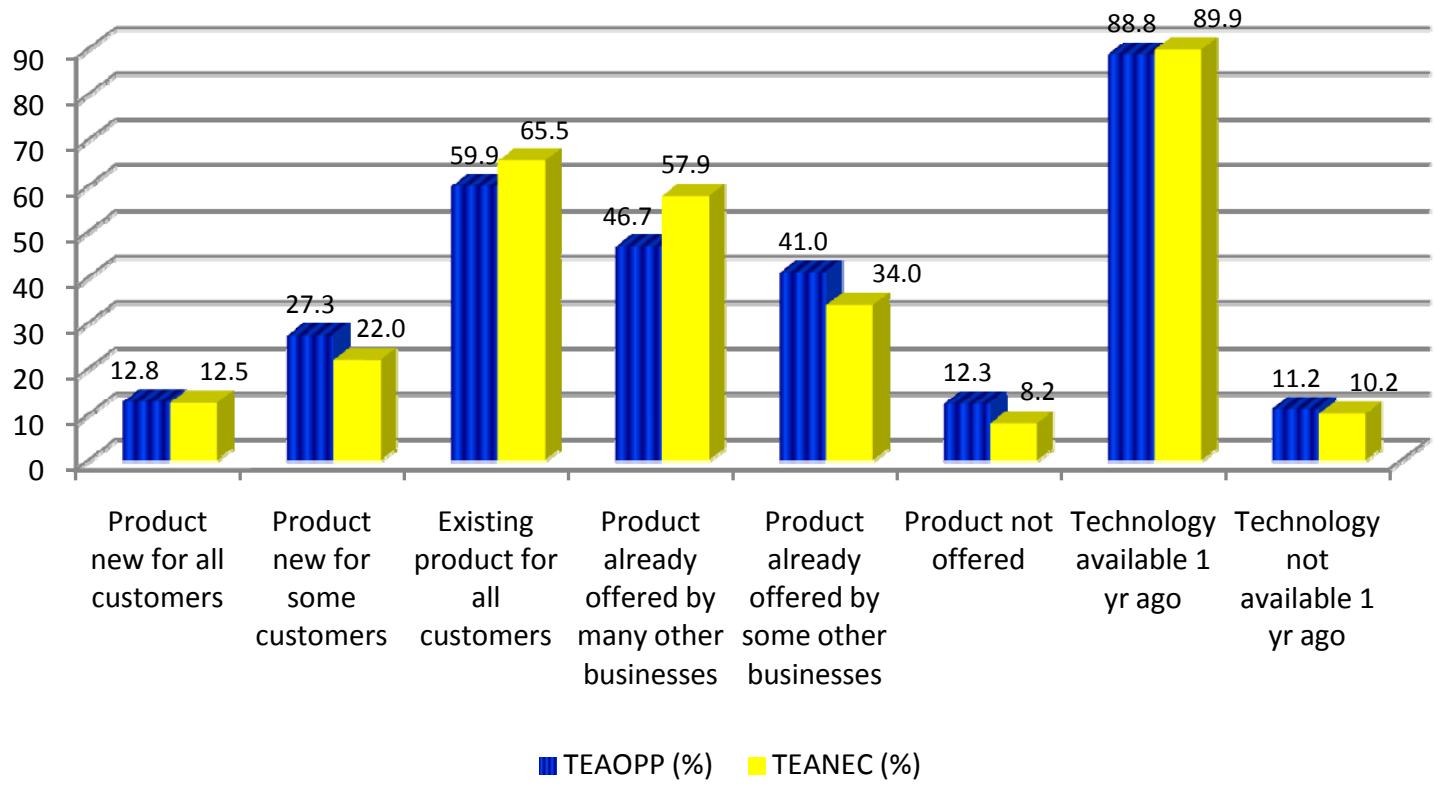

Domestic versus global markets

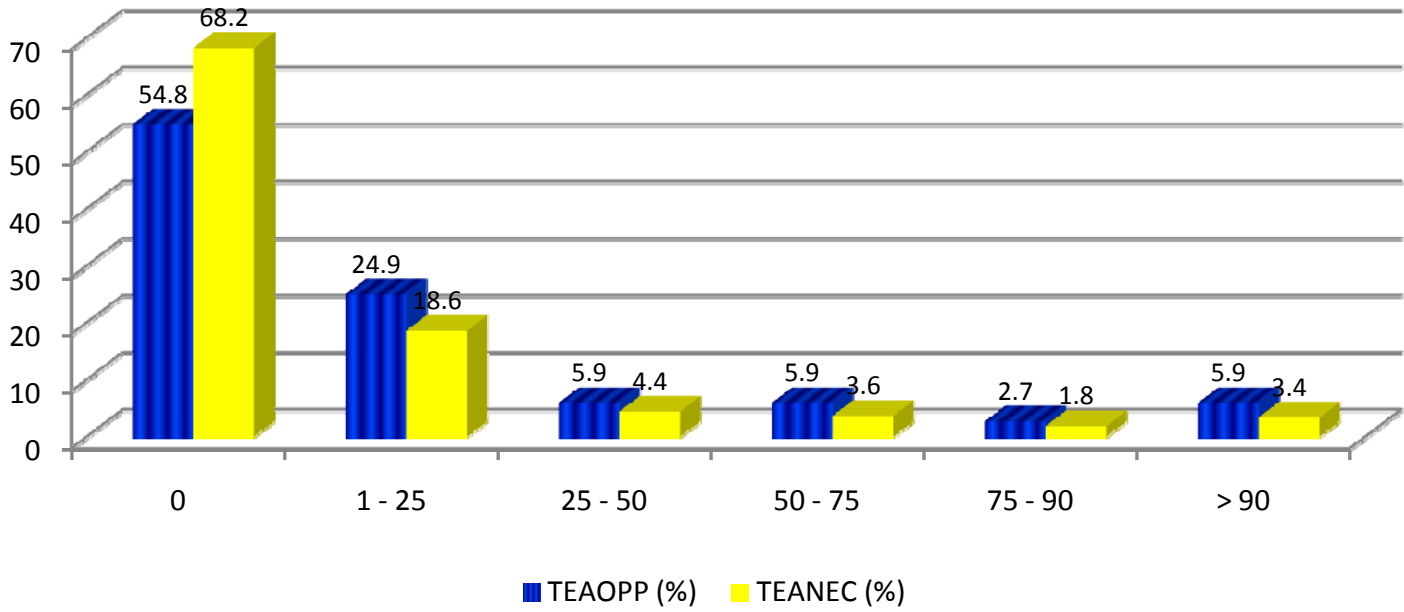

